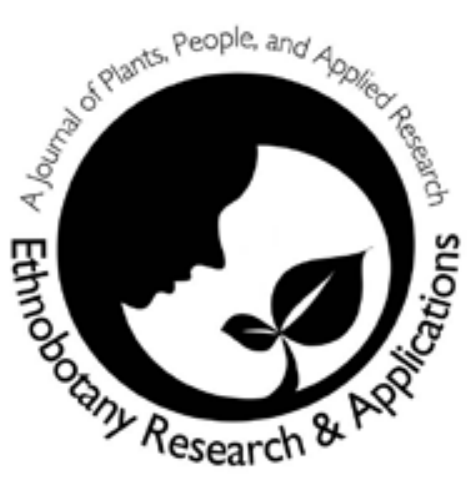

\title{
Survivor Rongelap: Health issues and use of traditional medicine among the women of Rongelap atoll
}

\author{
Jodi Stevens Releford and Will C. McClatchey
}

\section{Research}

\begin{abstract}
The people of Rongelap atoll have always been survivors. For centuries they survived in one of the most extreme environments in the world by making the most of the resources available to them. Life was further complicated when they were exposed to fallout from nuclear testing by the U.S. Consequently they have suffered horrible medical ailments and exile from their island home. With plans now in the works for repatriation to Rongelap atoll, safety is the first concern. We believe that the risk of consuming traditional plant-based remedies on Rongelap has been underestimated. Women and infants are particularly at risk because they utilize far more traditional remedies than the rest of the community. Some returning Rongelap Islanders may be consuming more than 60 times the number of remedies than was previously thought. We make some suggestions of ways to make the consumption of traditional remedies safe while still maintaining important cultural traditions.
\end{abstract}

\section{Introduction}

The recent history of the indigenous people of Rongelap Atoll of the Marshall Islands is one of deception, illness, and a love of their island home. Most recently it has become a quest for sustainability in the face of a nuclear holocaust. In the effort to return to their atoll home they are seeking to recreate an environment in which they can utilize natural resources conservatively and at the same time maintain traditional cultural practices. Issues of global sustainability encompass more than just conserving physical resources but also conserving traditional knowledge and way of life for indigenous peoples. Rongelap Islanders have been subjected to numerous physical and cultural challenges as a result of radiation exposure during the last generation.
For the atolls that now make up the Marshall Islands (Figure 1) to be habitable, the earliest Pacific explorers would have had to introduce useful plant species to the natural vegetation, which is sparse and simple (Figure 2). Atoll life for these early Marshall Islanders could not have been easy; and the fact that humans not only survived, but also flourished is a testament to their tenacity and resourcefulness. Unfortunately, in the modern era the lives of some Marshall Islanders, such as those from Rongelap atoll have been further complicated by numerous health problems as a result of radiation exposure. The United States began testing nuclear weapons in the northern atolls of the Marshall Islands following the end of World War II. The residents of Rongelap atoll (Figure 3) were temporarily relocated in 1946 during Operation CROSSROADS, the first round of tests, after which they were returned to their atoll (Simon 1997).

A few years later in 1954, BRAVO, the first test of Operation CASTLE, was detonated on neighboring Bikini atoll. The BRAVO test resulted in an explosive yield "three times the most probable predicted value and twice the

\section{Correspondence}

Jodi Stevens Releford, Department of Botany, University of Hawai' $i$ at Manoa, Honolulu, Hawai'i, U.S.A.

jstevens@hawaii.edu

Will C. McClatchey, Botanical Research Institute of Texas, Fort Worth, Texas, U.S.A.; Department of Botany, University of Hawai i at Manoa, Honolulu, Hawai' i, U.S.A.; Texas Christian University, Fort Worth, Texas, U.S.A.

wmcclatchey@brit.org

Ethnobotany Research \& Applications 9:287-305 (2011)

Published: July 31, 2011 


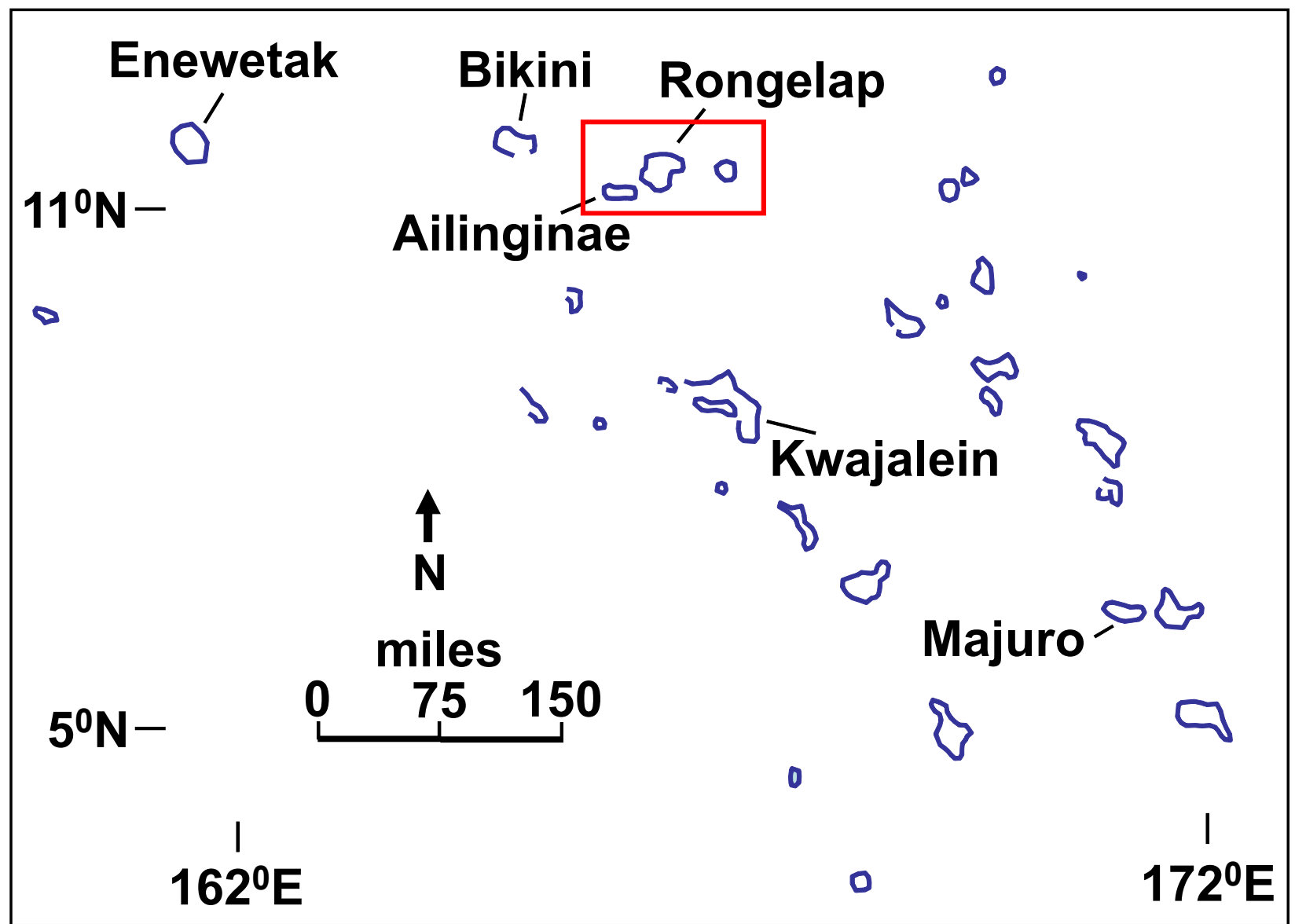

Figure 1. Republic of the Marshall Islands in the North Pacific Ocean with pertinent atolls labeled. Boxed area includes atolls traditionally managed by people of Rongelap atoll.

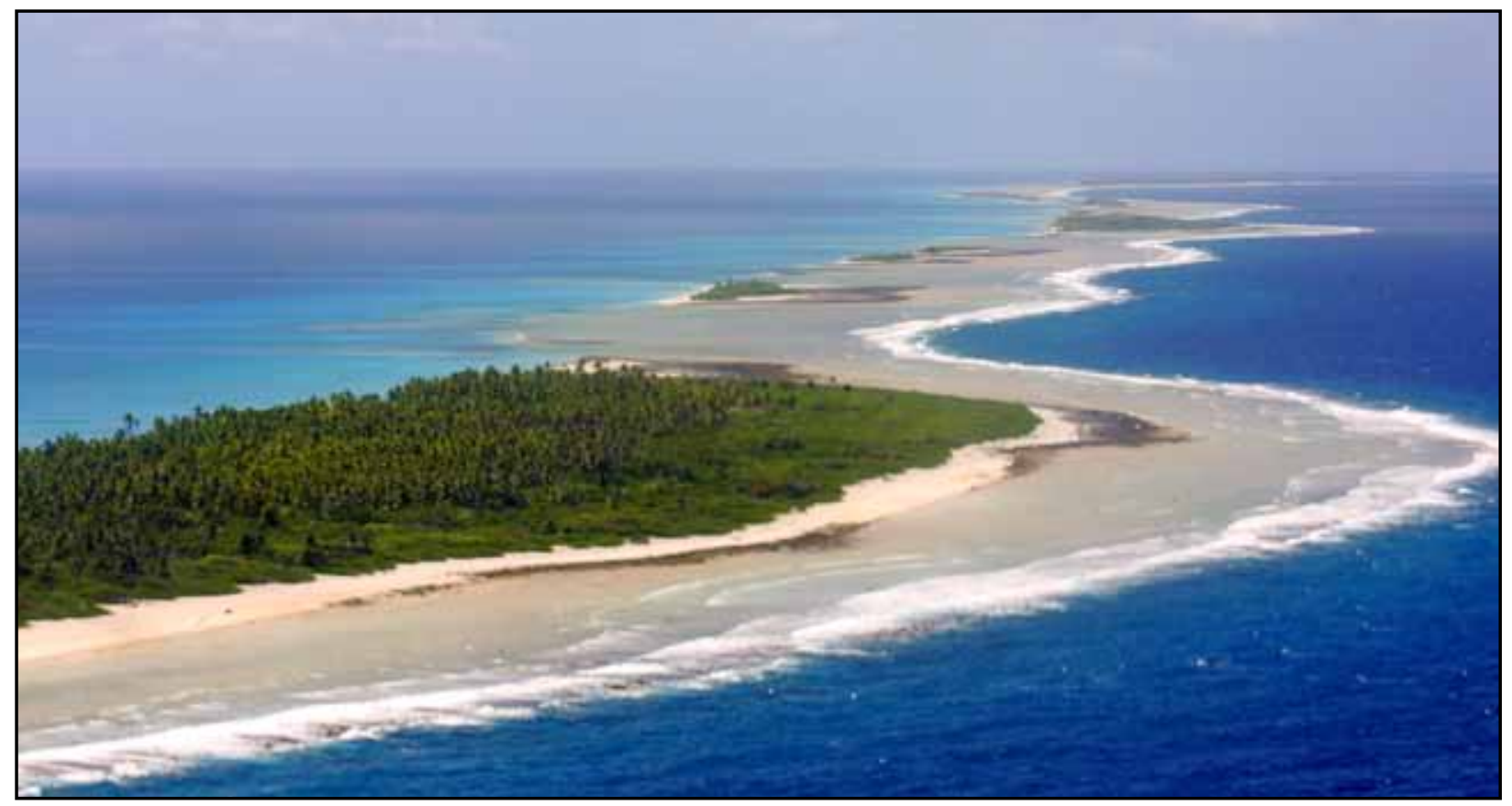

Figure 2. The northeast end of Rongelap atoll, Republic of the Marshall Islands. 

of traditional medicine among the women of Rongelap atoll

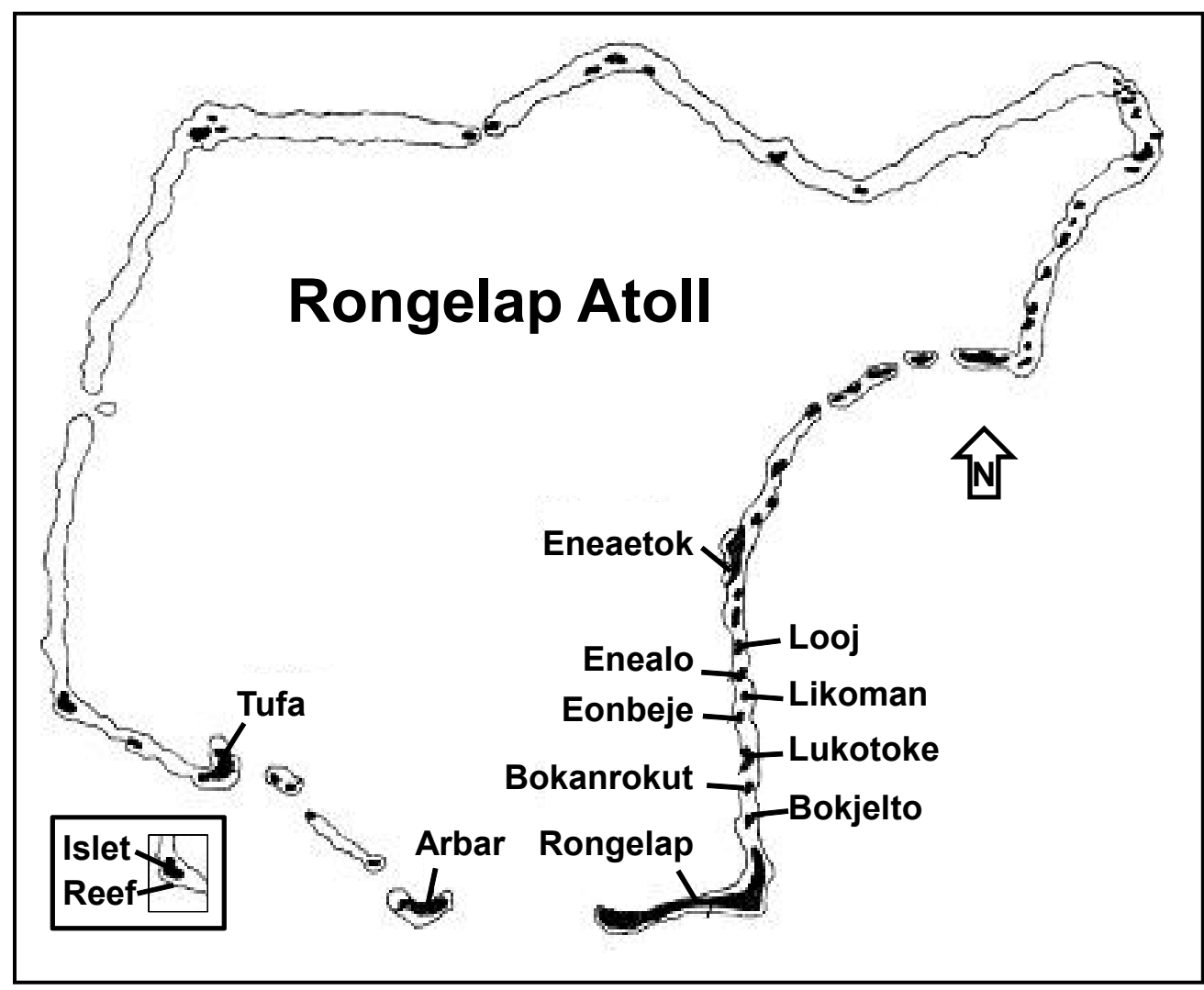

Figure 3. Rongelap atoll, Republic of the Marshall Islands with surveyed islets labeled. predicted upper limit" (Defense Nuclear Agency 1954). The bomb was 400-500 times larger than those dropped on $\mathrm{Hi}-$ roshima and Nagasaki (Weisgall 1994). In fact, the resulting explosion was equal to 15 million tons of TNT (Yamazaki 1995) and released one hundred and fifty-seven times the amount of radioactive iodine into the atmosphere than the Chernobyl accident (Plasman 2005).

The BRAVO bomb was detonated near the ground "so that large quantities of earth, sand, and water were admixed and fused with the radioactive fission products. The in-

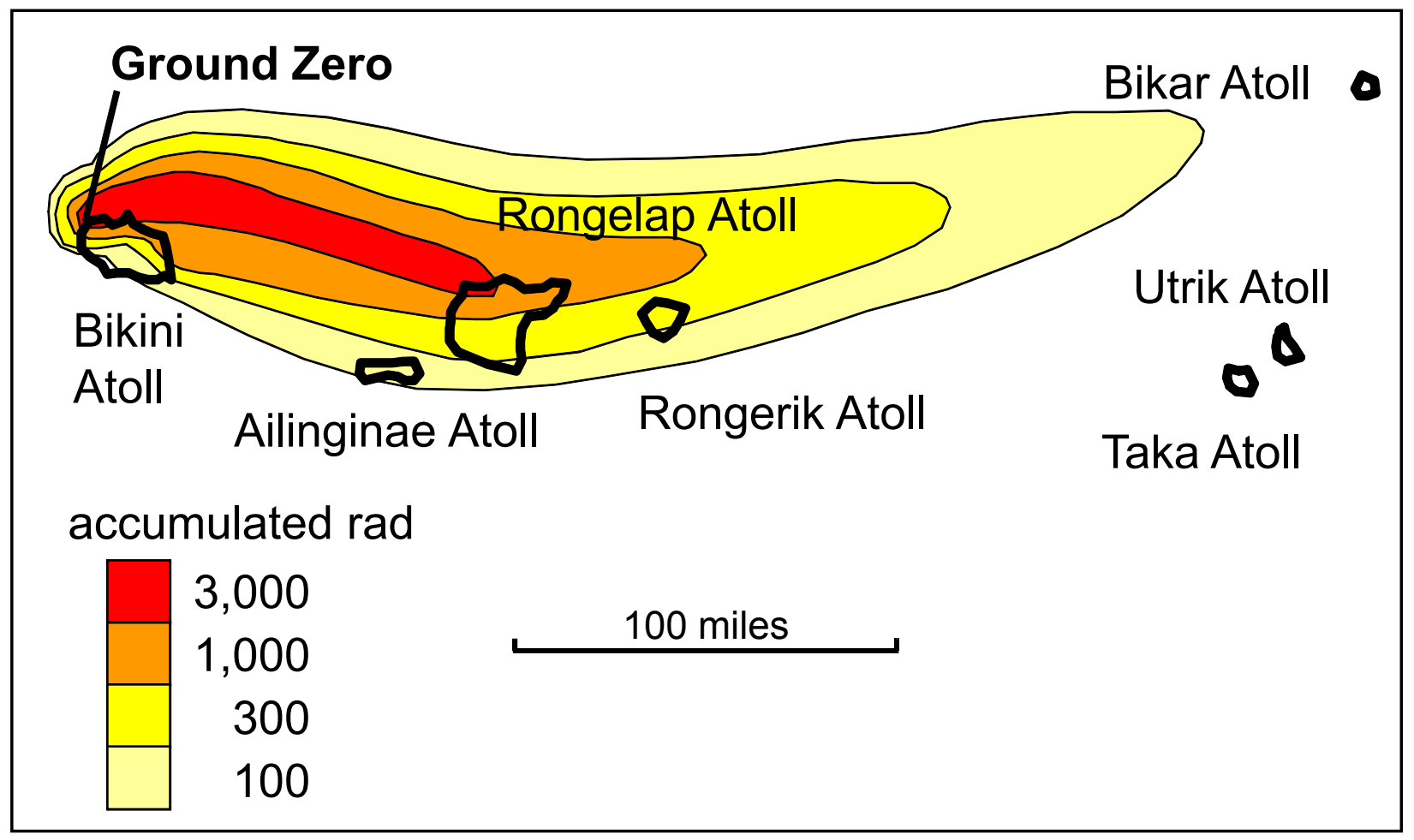

Figure 4. Wind distributed nuclear fallout pattern from the BRAVO detonation at Bikini Atoll in 1954 including Rongelap and Ailinginae where Rongelap Islanders were living at the time. After Robison et al. 1997. 
tense heat lofted this cloud of lethal materials high above the surface, forming a cloud more than 120 miles long and 30 miles wide. As the cloud cooled, much of the radioactive content returned to the earth as a powdery shroud. The fallout particles clung to the skin of people exposed to the powdery 'rain.' The fallout was inhaled as people breathed and it was ingested when they ate contaminated food. Particles in the environment and on the skin of the people emitted gamma rays, which penetrated their bodies, and beta rays, which burned their skin" (Yamazaki 1995). Winds blowing northeast at high elevation transported heavy radioactive fallout to several nearby atolls (Figure 4) including Ailinginae, Rongelap, Rongerik, and Utrik (Defense Nuclear Agency 1979, Whitcomb 2000).

Jon Anjain, the Magistrate of Rongelap at that time, later described the events of the day, "we saw a flash of lightning in the west like a second sun rising. We heard a loud explosion and within minutes the ground began to shake. A few hours later the radioactive fallout began to drop on the people, into the drinking water, and on the food. The children played in the colorful ash-like powder. They did not know what it was and many [sores] erupted on their arms and faces". More than two days passed before the people of Rongelap were removed. In that time, "our people began to be very sick, they vomited, burns showed on their skin, and people's hair began to fall out," remembered Anjain (Wasserman et al. 1982).

The United States military eventually evacuated the 82 residents of Rongelap to Kwajalein atoll for medical treatment, and then in June of 1954, to Ejit on Majuro atoll (United States Atomic Energy Commission 1957). When the U.S. came to evacuate the community, they were told not to bring any of their belongings; no personal papers, no family heirlooms etc. and most of their belongings were subsequently destroyed during their exile (Johnston \& Baker 2008). The Rongelap islanders were permitted to return to their atoll in 1957, despite their concerns of safety. These concerns later proved valid as the women of Rongelap experienced a stillbirth and miscarriage rate twice that of other Marshallese women not exposed to the radioactive fallout (Wasserman et al. 1982). According to a Brookhaven study, body radiation levels of Rongelap Islanders had risen to sixty times normal for cesium and six times for strontium 90 by 1961 (Johnson 1979).

The Rongelap community became convinced that the island was not safe for human habitation, despite U.S. efforts to convince them otherwise. In fact, according to Suzanne Murphy (2005) of the Marshall Islands Journal, Harvey Feldman, the U.S. Ambassador to the United Nations, went so far as to say that, "Rongelap was no more dangerous than Washington $\mathrm{DC}$ - and that locally grown food consumption would receive less radiation than residents of Denver Colorado." Because so many community members were becoming ill, the Rongelap community finally made the decision to leave the island. Lemeyo
Abon, a BRAVO survivor, remembers, "We thought if we moved from our land the US would finally consider our plight. It was a gamble with our lives. But we knew we were contaminated. Our main concern was the safety of our children and grandchildren. So many people were getting sick. All we wanted was for the US to clean our island" (Murphy 2005).

Without scientific evidence that the atoll was contaminated, they were unable to convince U.S. or Marshall Islands National government leaders to help them financially and logistically in the evacuation. Without governmental assistance, the people of Rongelap turned to Greenpeace to help them. So it was that in 1985, three hundred Rongelap Islanders were once again evacuated from Rongelap (Figures 5,6 ) to Majetto (an islet in Kwajalein atoll) and Majuro, where most of them remain to this day (Greenpeace 2005). Consequently, Rongelap Islanders have a complex evacuation history and are still living with the effects of artificial environmental radiation exposure.

The immediate medical effects of exposure included burns to the skin, hair loss, festering sores (Simon 1997), and eventually stillbirths and congenital abnormalities (Pollock 2004). The women of Rongelap in particular, suffered from the effects of exposure. Lijon Eknilang, a BRAVO survivor, explains, "I cannot have children. I have had miscarriages on seven occasions. On one of those occasions, I miscarried after four months. The child I miscarried was severely deformed; it had only one eye. I have also had thyroid surgery to remove nodules. I am taking thyroid medication which I need every day for the rest of my life. Doctors recently found more nodules in my thyroid, which have to be removed in the near future. I have lumps in my breasts, as well as kidney and stomach problems, for which I am receiving treatment. My eyesight is blurred, and everything looks foggy to me" (The Hague 1995).

Almira Matayoshi lost both of her parents to cancer, and has had five post BRAVO pregnancies that resulted in stillbirths. She was pregnant and living on Rongelap at the time of the blast, and gave birth to what is called a "jellyfish baby" shortly after (Hoover 2003). According to the women of Rongelap, jellyfish babies are born with no bones in their bodies and their skin is transparent so that one can see their heart and brains. These babies usually died within days of birth. Apparently, these types of abnormalities did not exist among this population prior to exposure (Keju-Johnson 2003, The Hague 1995).

In the four years following the BRAVO blast, one in every three births in the Marshall Islands resulted in fetal death (Dibblin 1988). Among the Women of Rongelap between 1957 and 1963, there were twice the number of "abnormally terminated" pregnancies (Kohn 1989). Unfortunately, while the women were convinced that these abnormalities were linked to their exposure, the male dominated medical teams from the U.S. failed to acknowledge the 


\section{Stevens Releford \& McClatchey - Survivor Rongelap: Health issues and use of traditional medicine among the women of Rongelap atoll}

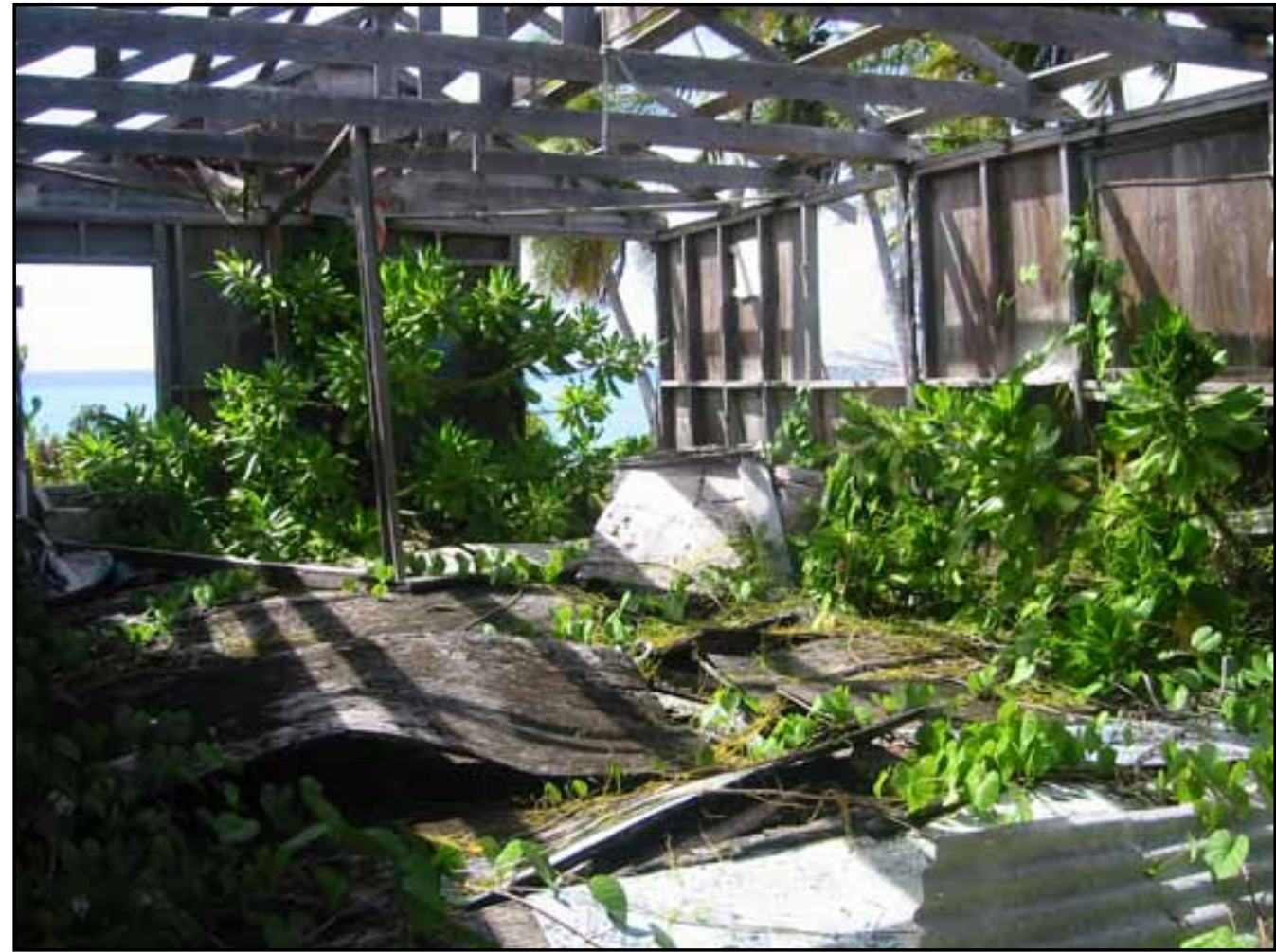

Figure 5. One of the homes abandoned in 1985 when the Rongelap Islanders were evacuated from Rongelap atoll, Republic of the Marshall Islands.

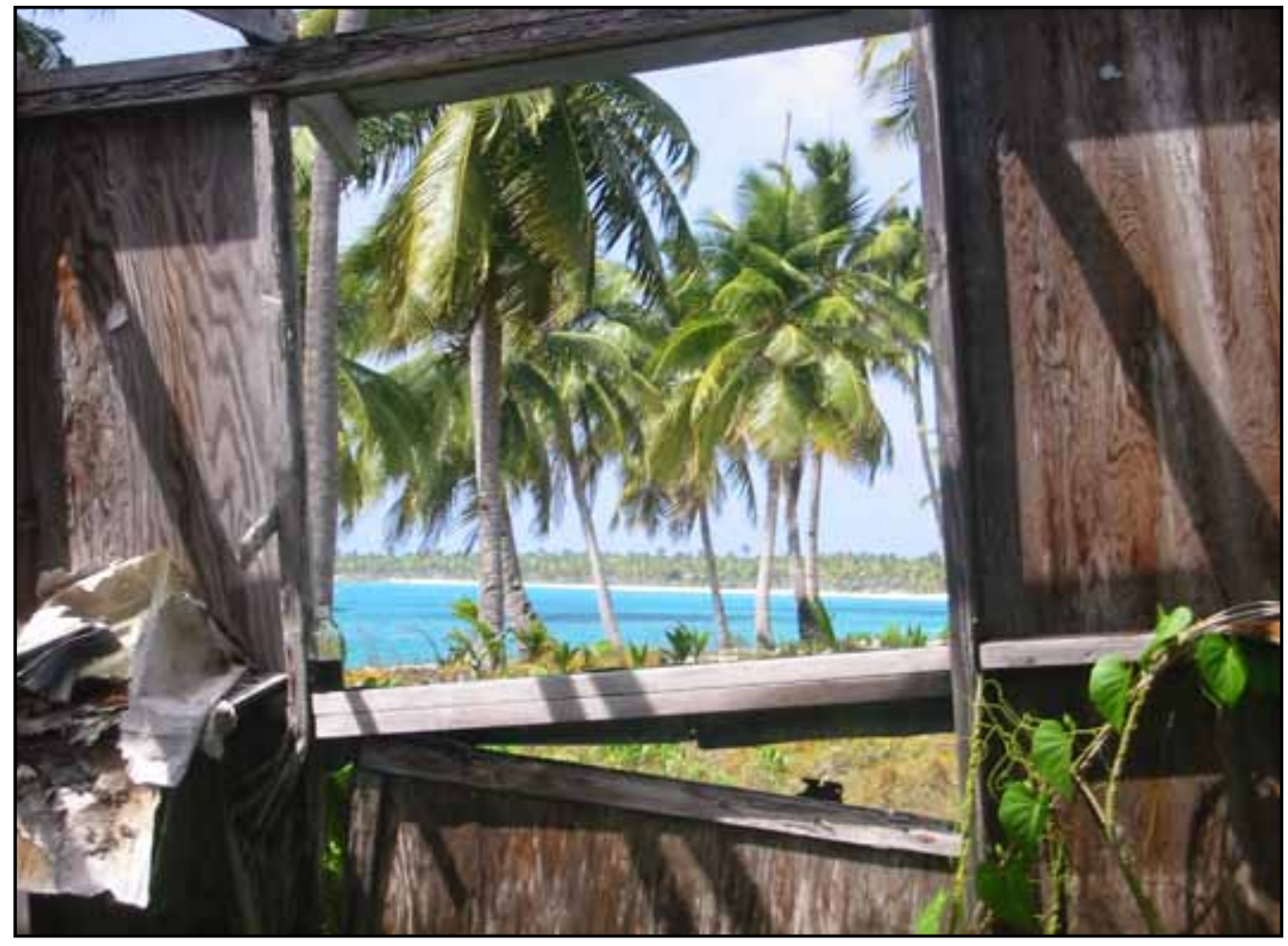

Figure 6. View from the window of an abandoned home on Rongelap atoll, Republic of the Marshall Islands that still had some of the former occupant's belongings in it. existence of these babies, and the births went largely unrecorded (Pollock 2004). Therefore, there is very little information available about these abnormalities, beyond the women's stories and some photographs. Within the Marshall Islands, there is a cultural belief that reproductive abnormalities are a sign of infidelity (The Hague 1995) as a result; women have endured these pregnancies and births quietly.

Giving birth to a normal child did not guarantee that they would be healthy. Chiyoko Tamayose has 12 children; some of whom are physically handicapped. "I have one son who had liver cancer; he was operated on ....in Honolulu and he died during the operation. He left a family of four children and a wife. Another son had problems with his thyroid so severe that he could not eat or swallow water. A daughter was born with the lower body so soft as if there was no bone. I have a 40 year old son who was born with a 
good sized blister on his back... He became paralyzed" (Tamayose 2005).

Members of the Rongelap community have suffered from a high incidence of thyroid disease and cancer (Johnson 1980, Wasserman et al. 1982). Thyroid disease has been the most prevalent medical consequence of the BRAVO blast among Rongelap Islanders. As of 2006, 1,186 personal injury claims for thyroid disease had been filed with the Nuclear Claims Tribunal (the organization within the Republic of the Marshall Islands that deals with the claims of potential radiation related illness) by exposed Marshall Islanders (Johnston \& Baker 2008). The women and children of Rongelap have suffered the most from the effects of thyroid illness. The people of the northern atolls, including those of Rongelap and Ailinginae, are expected to experience $95 \%$ of all radiation related thyroid cancers in the Marshall Islands (National Cancer Institute 2004). The risk of thyroid disease was reported to be twice as high among exposed females than exposed males (Howard et al. 1997, Takahashi et al. 2003). Additionally, $84 \%$ of children who were ten years old or younger when they were exposed, have since developed thyroid nodules (Stanbury 1970), and at least five of the 19 children originally exposed to the BRAVO blast showed signs of growth retardation attributable to thyroid abnormalities (Conard 1976).

In a recent study by the U.S. National Cancer Institute ( $\mathrm{NCl} 2004)$, it was estimated that within the lifetime of Marshall Islanders alive at the time of exposure, 530 cancers (leukemia, thyroid cancer, stomach cancer, colon cancer, and others) would develop that could be attributed to exposure from radioactive fallout. Because of the young age structure of the population in 1954, and the fact that cancers may take decades to develop, $56 \%$ of the predicted cancers had yet to develop at the time of the study. Further, approximately $87 \%$ of all of the radiation related cancers in the Marshall Islands have been predicted to affect individuals exposed on the northern atolls including Rongelap. Unfortunately, the $\mathrm{NCl}$ estimates were based on measurements from urine samples taken shortly after evacuation. Consequently, they did not take into account subsequent radiation exposure from resettlement of heavily contaminated atolls. As a result, it is possible that the $\mathrm{NCl}$ has underestimated the total number of radiationinduced cases of cancer within the Marshall Islands (Harvard Law Student Advocates for Human Rights 2006) as a whole and particularly within the Rongelap population.

There has been much criticism of the way in which the United States treated the Marshallese in general, and Rongelap Islanders in particular. From unclassified documents it seems clear that the U.S. knew for some time prior to the BRAVO test that the weather conditions were less than favorable and that the fallout would expose islanders on Rongelap and Ailinginae and other northern atolls. In fact, U.S. ships in the area were moved further from the blast zone, yet the islanders were not moved or warned of the danger (Weisgall 1994). Whether or not this was done with malicious intent we may never know, but at the very least it was grossly negligent.

Later, communication between scientists and the Rongelap community was spotty at best. Scientists suspected that the atoll was still contaminated and that the Rongelap Islanders were at risk, yet did not communicate these concerns to the community. It was not until 1982 that the Rongelap Islanders were told that the northern islets within the atoll were still highly contaminated and that they should not visit them or consume plants and animals collected from the area (Department of Energy 1982). There seems to have been little effort to educate Rongelap Islanders of the possible risks prior to the publication of the 1982 report. In fact, some scientists were condescending to Rongelap Islanders and thought that they were not intelligent enough to understand what was happening. When Rongelap Islanders got blisters on their lips and mouths and suffered stomach pains after eating fruits and fish from the contaminated atoll, U.S. doctors and officials told them that they were preparing the foods incorrectly (The Hague 1995). Of course this was ludicrous; they had been preparing those foods for centuries without experiencing these side effects. Edward T. Lessard, a health physicist from Brookhaven, who led the Marshall Islands radiological protection program between 1981 and 1987, said: "We couldn't educate them. They don't even have a word for radioactivity" (Weisskopf 1988). While doctors treating the Bikinians ordered their evacuation in 1978 (Woodard 1998), medical records that may have raised questions of safety on Rongelap were left undocumented and unavailable to Rongelap Islanders for 30 years (Weisskopf 1988).

The lack of education and communication of possible health concerns have led some to believe that the Rongelap Islanders were used as test subjects, or guinea pigs by the U.S. James Matayoshi, Mayor of Rongelap, believes that documents referring to Rongelap Islanders as "test subjects", "control groups", and as "more similar" to Americans than lab mice (Woodard 1998) are evidence that this is the case. A hearing of the House Natural Resources Committee held in 1994, reexamined the BRAVO test and the events that followed, and while they found evidence that the U.S. knew about the wind shift and should have evacuated the people of Rongelap, they found no evidence to support the theory that they were deliberately exposed as part of a U.S. experiment to document the effects of radiation (Crane 1994). At best the U.S. was negligent and dismissive to the Rongelap Islanders, and at worst they used them experimentally to observe the effects of radiation exposure on humans first hand.

In a speech commemorating the fiftieth anniversary of the BRAVO detonation, Mayor Matayoshi expressed the feelings of the Rongelap people regarding their ordeal. 


\section{Stevens Releford \& McClatchey - Survivor Rongelap: Health issues and use 293 of traditional medicine among the women of Rongelap atoll}

"The testing program in the Marshall Islands was equivalent to several Hiroshima bombs every week for 12 years. Our islands were ground zero in the Cold War, and we were on the front line in the fight to win the Cold War... The US needed the Marshall Islands to win the Cold War. That is what the US Congress and US Presidents told us over and over again... We understood that the stakes were high for all mankind. We understood better than most people because we were victims of radiation poisoning in our bodies and in our homeland. We understood that it was a struggle between good and evil, and that sometimes sacrifices have to be made in the pursuit of the good. We understood, but that does not change the reality. We were not protected from danger when we could have been taken to safety." (Matayoshi 2004)

While a number of radionuclides contributed to the exposure of Rongelap following the BRAVO blast, the radionuclide that poses the greatest exposure risk presently is cesium $\left({ }^{137} \mathrm{Cs}\right)$ since it "contributes $>95 \%$ of the external and internal dose to Marshallese" (Robison et al. 1988). The primary contribution to overall dose of ${ }^{137} \mathrm{Cs}$ is through ingestion of contaminated plant and animal foods (Robison et al. 1997, 1982). According to bioavailability studies from Bikini atoll, cesium is the radionuclide that is most efficiently transported from soil to vegetation through root uptake (Colsher et al. 1977). Rongelap Islanders returning to the atoll have been advised by The National Research Council (1994) to supplement their local diet with imported foods as a safeguard against exceeding exposure limits. Unfortunately, the Research Council did not include the use of medicinal plant-based remedies and their contribution to exposure levels in their guidelines. In fact, while several studies have reported concentrations of ${ }^{137} \mathrm{Cs}$ in the Rongelap environment including some plant species (Colsher et al. 1977, Koranda et al. 1978, Nelson 1977), only one group (Duffy et al.1999) has taken into account the use of medicinal plants by returning members of the Rongelap community.

In their work, Duffy and her colleagues endeavored to quantify the level of exposure to the people of the Marshall Islands resulting from the use of medicinal plantbased remedies. While their work is a good start, they made some invalid assumptions about medicinal plant use among Marshall Islanders. First, they considered only five (Morinda citrifolia L., Microsorum scolopendria (Burm.f.) Capel, Scaevola taccada (Gaertner) Roxb., Tournefortia argentea L.f., and Triumfetta procumbens G. Forst.) of the more than sixty plant species (Merlin et al. 1994, Muller \& Vander Velde 1999, Nandwani \& Dasilva 2003, Taafaki et al. 2006) previously reported as medicinal throughout the Marshall Islands. Secondly, they made the assumption that individuals would consume only six remedies (one remedy made from the leaves of each of the five species and one made from the fruit of $\mathrm{M}$. citrifolia) in a year, thus exposure would be kept to a minimum. Although it was suggested that individuals who frequently ingested plant-based remedies would increase their risk of exposure, it was implied that those individuals would be the exception and not the rule. They obtained their data regarding medicinal plant use from "knowledgeable local residents" such as the curator of the natural history museum and a Fijian healer. They did not spend time with Marshallese healers and thus received very basic information regarding medicinal plants and their usage. And finally, since the majority of the most contaminated northern atolls were uninhabited at the time of the study, they assumed they would remain so, even though plans were already underway for the repatriation of Rongelap and $\mathrm{Bi}$ kini atolls.

Rongelap islanders are certainly not the only indigenous people to be affected by the nuclear age. Five of the nations that have tested nuclear weapons in the last 50 years have done so on the lands of indigenous peoples including other Pacific Islanders, Australian Aborigines, the Kazakhs, Tibetans, and the Western Shoshone of North America (Brooks \& Hu 1995, Johnston et al. 1992, Leubben 1988, Simon \& Bouville 2002). In fact, the Pitjantjatjara, an Australian Aboriginal cultural group, were also displaced from their tribal lands and returned with concerns of contamination and cultural change (Cooper et al. 1994). Others like the Sami of Norway have had to change cultural traditions and ways of life as a result of contamination from Chernobyl (Stephens 1997). Because culture is closely linked with the land in many indigenous cultures, they stand to lose much from contamination of their environment. Having to leave their lands and/or change cultural traditions such as traditional food production and preparation to avoid exposure may result in the loss of specific cultural elements (Stephens 1995). Likewise, Rongelap Islanders will have to make such changes in order to live safely on Rongelap Atoll.

\section{Hypothesis}

The women of Rongelap have clearly suffered as a result of their exposure to radionuclides. Not only have they had numerous health concerns themselves, but have also watched their children suffer, and have worked to relieve the suffering of others. These women have done this while also providing for the needs of daily life in a hostile atoll environment without having the assistance that they needed and deserved. While the community is excited at the prospect of returning to live on Rongelap after so many years away, theirs is a cautious optimism and rightly so.

Considering the cultural importance of women in the Rongelap community and the nature of women's cycles, we hypothesized that Rongelap women and female infants will utilize more plant-based remedies than men and older children. As a result, the women and infants will be the members of the community at highest risk of increased levels of dangerous radionuclide exposure. Based on his- 
torical accounts and a recently published pharmacopoeia (Taafaki et al. 2006) of actively practicing Marshallese healers, we believe the level of exposure to cesium from the use of traditional medicine has been underestimated particularly for women and infants.

Within the Marshallese culture, women traditionally fill the roles of nurturers and caregivers. As a result, most Rongelap healers are women. This is also likely due to the fact that women tend to have more health concerns than men in general. Because of this fact, we hypothesize that the women will be doing the majority of the collecting and preparing of plant-based remedies on Rongelap. This additional contact with possibly contaminated plant material may further increase the risk of exposure for healers necessitating some changes in the collection, preparation, and administration of traditional remedies.

\section{Methods}

Because of the removal of the Rongelap community from the atoll, there were questions and concerns regarding which plant species were presently available on the island. As invited guests of the Rongelap government, we were asked to collect and catalog the local flora and ethnobotanical information regarding medicinal plants important to the repopulation effort. Government officials and Rongelap elders assisted in the research by providing ethnobotanical

information, assistance in collection, and the use of local (on Rongelap and Majuro) facilities and equipment. The data were collected on Majuro and Rongelap atolls in April and June of 2001 and 2002.

The flora of the atoll was documented using an ethnobotanical inventory (Cunningham 2001) that included an initial plant collection on the atoll using a list of plants previously reported (Taylor 1950) to exist on the atoll. Members of the Rongelap community with knowledge of the atoll and the plant species assisted me during this initial collection and initiated the interview process by participating in individual and group field interviews (Martin 1995, Prance et al. 1987). Each of the plants collected during this process were discussed in greater detail with initial participants and other Rongelap Islanders using the inventory interview technique described by Boom (1989). Further, ethnographic interviewing techniques (Spradley 1979) including plant interviews (Figures 7 and 8) (Boom 1987, Alexiades 1996) and focus groups (Alexiades 1996) or participatory-group interviews (Cunningham 2001) with Rongelap Islanders took place on Rongelap and Majuro atolls.

The use of focus groups (Figure 9) became very important to this study because many participants felt uncomfortable talking with me individually. While there are many reasons for this, the two most common were a feeling of embarrassment regarding their use of English, or a feeling that others knew much more than they did individually. When in a group setting, the participants were much more likely to participate and insert their knowledge as they felt comfortable. The group discussion also assisted in jogging many memories.

Voucher specimens (Martin 1995, Merrill 1981) were collected with permission from the Rongelap government

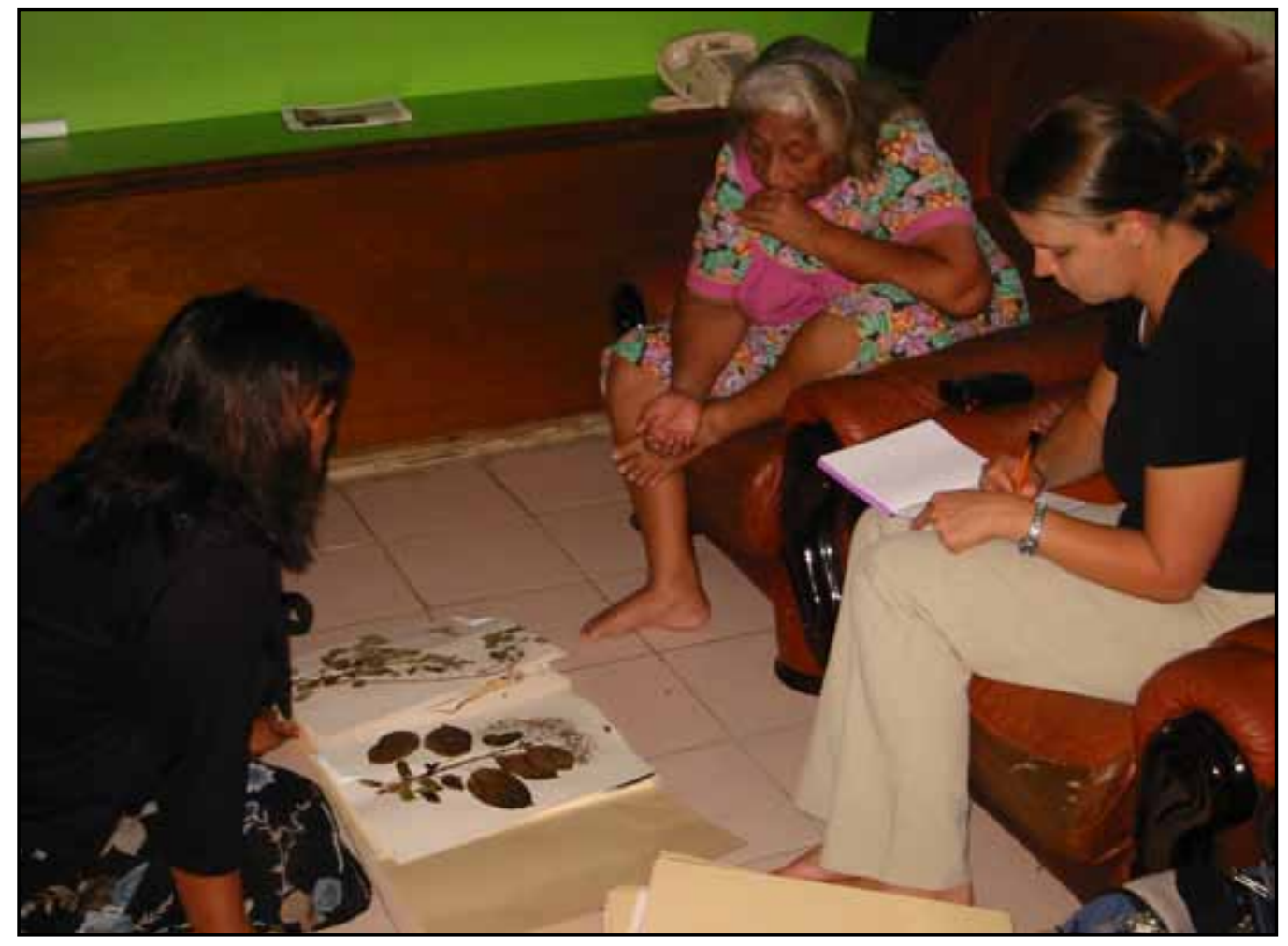

Figure 7. A plant interview with a Rongelap healer on Majuro Atoll using voucher specimen from Rongelap Atoll. 


\section{Stevens Releford \& McClatchey - Survivor Rongelap: Health issues and use of traditional medicine among the women of Rongelap atoll}

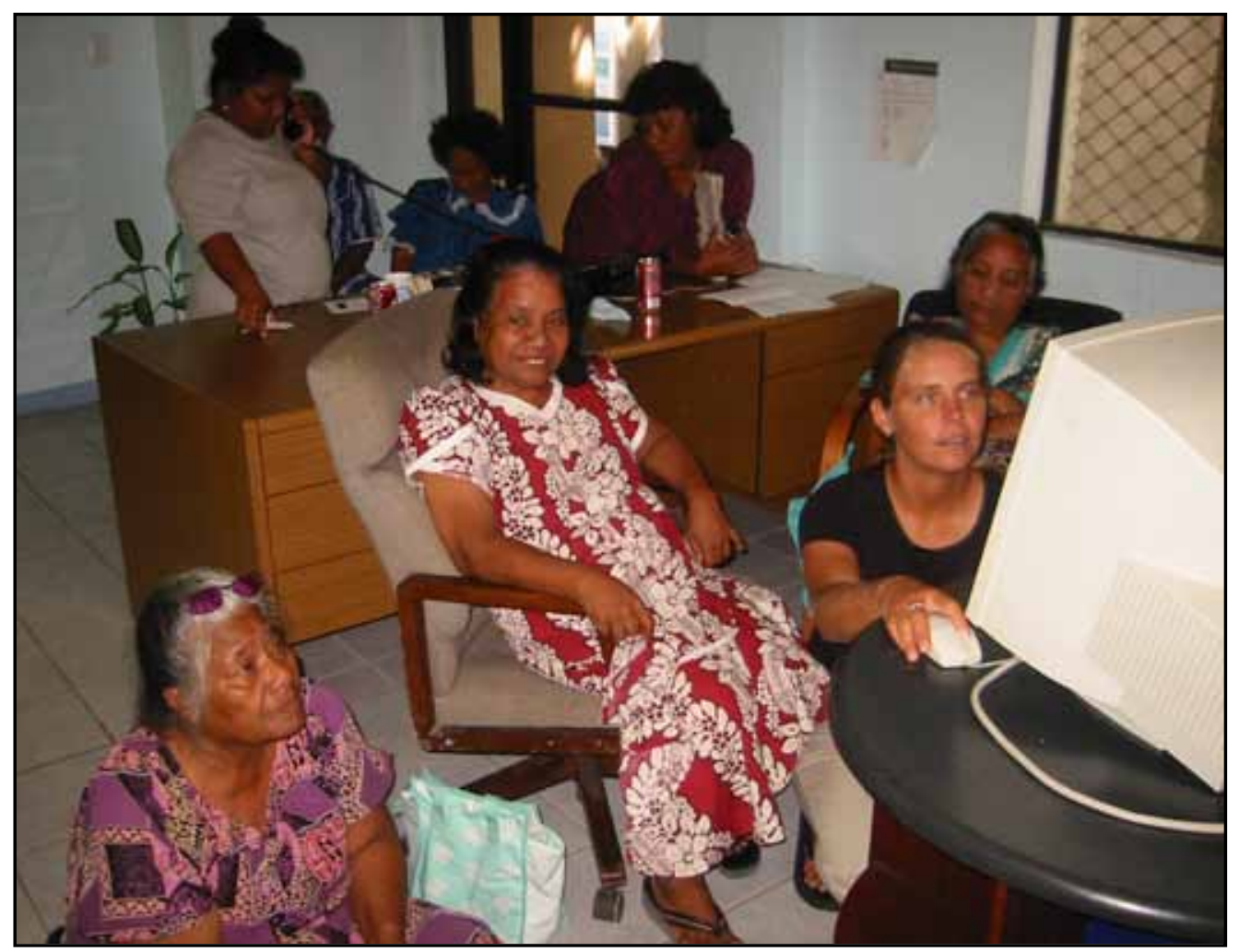

Figure 8. A plant interview with a group of Rongelap Island women on Majuro Atoll using digital photographs to identify and discuss plants found on Rongelap but not Majuro.

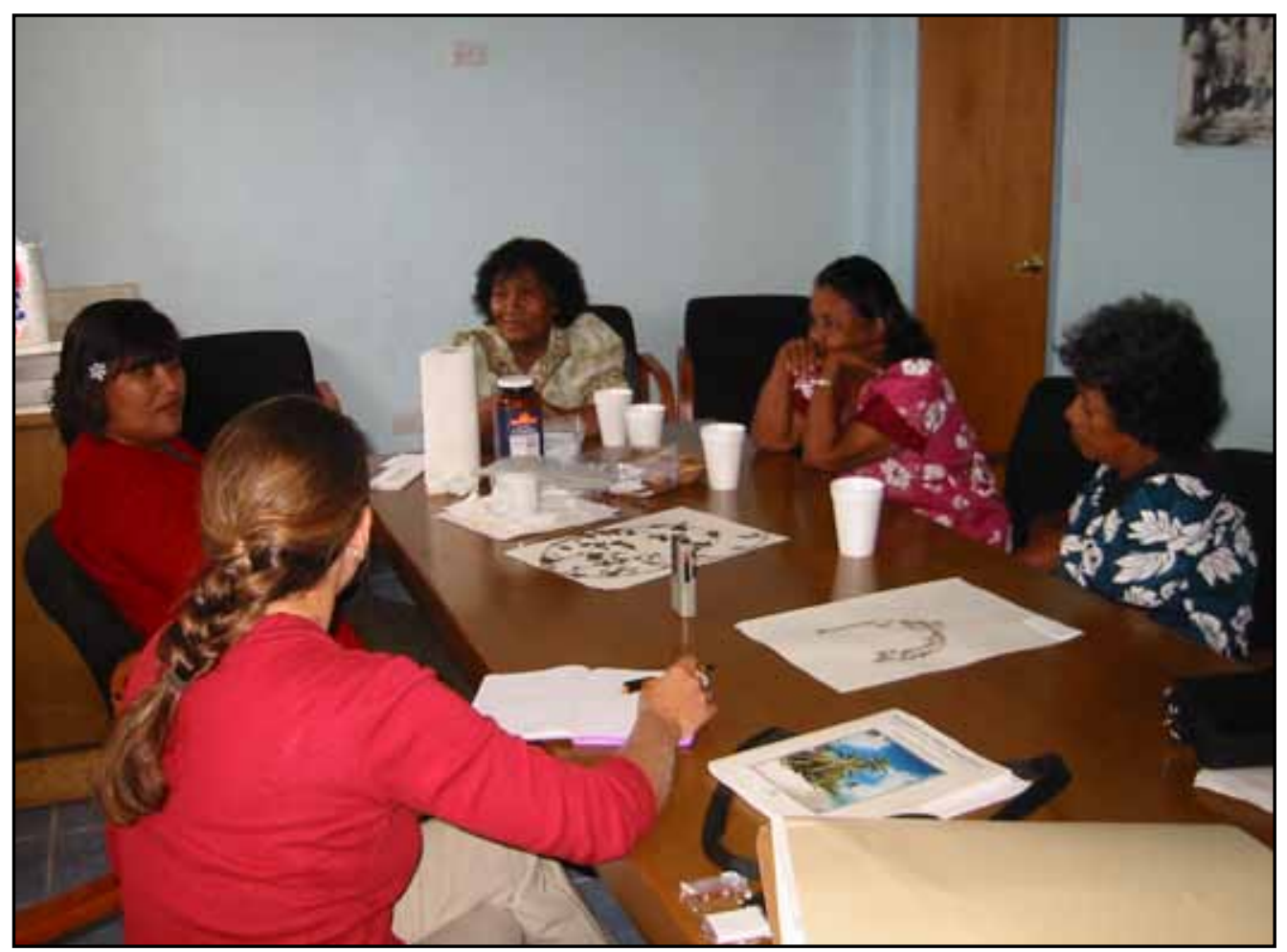

Figure 9. A focus group of Rongelap women discussing medicinal plants. and indigenous landowners and prepared in triplicate for all plants discussed in the interview process. The plant vouchers collected were deposited in the herbarium of the University of Hawai'i at Manoa (HAW) in Honolulu Hawai'i.

\section{Results}

Table 1 is a list of Rongelap medicinal plants and includes the number of remedies in which each plant is used. The remedies are categorized by those used by men, women, children, and general treatments. Detailed information regarding medicinal plant species used by Rongelap Islanders can be found in Stevens Releford (2009). Of the 39 identified medicinal species used by Rongelap Islanders, 26 are used in remedies for female ailments including menstruation, pregnancy and childbirth. Forty-one, or $25 \%$ of the 165 total remedies collected were utilized solely for woman, while only two were exclusive to men. A general discussion of traditional remedies 
Table 1. Rongelap medicinal plants and the number of remedies that utilize each species. The total number of remedies is further broken down into four categories based on which members of the community use those remedies.

\begin{tabular}{|c|c|c|c|c|c|c|}
\hline \multicolumn{2}{|r|}{ Names } & \multicolumn{5}{|c|}{ Treatments } \\
\hline Rongelap & Scientific & for Women & for Children & for Men & General & Total \\
\hline Armwe & $\begin{array}{l}\text { Pipturus argenteus } \\
\text { (G. Forst.) Wedd. }\end{array}$ & 1 & 0 & 0 & 0 & 1 \\
\hline Atat & $\begin{array}{l}\text { Triumfetta } \\
\text { procumbens G. Forst. }\end{array}$ & 3 & 6 & 0 & 3 & 12 \\
\hline Bõb & $\begin{array}{l}\text { Pandanus tectorius } \\
\text { Sol. ex Parkinson }\end{array}$ & 2 & 2 & 0 & 4 & 8 \\
\hline Dãbijdekã & $\begin{array}{l}\text { Boerhavia tetrandra } \\
\text { G. Forst. }\end{array}$ & 0 & 0 & 0 & 1 & 1 \\
\hline Ekkõñ & $\begin{array}{l}\text { Terminalia samoensis } \\
\text { Rech. }\end{array}$ & 2 & 1 & 0 & 2 & 5 \\
\hline Joñ & $\begin{array}{l}\text { Bruguiera gymnorrhiza } \\
\text { (L.) Sav. }\end{array}$ & 1 & 0 & 0 & 1 & 2 \\
\hline Kaar & Premna serratifolia L. & 2 & 0 & 0 & 1 & 3 \\
\hline Kalañe & Suriana maritima L. & 0 & 0 & 0 & 1 & 1 \\
\hline Kañal & Pisonia grandis R.Br. & 1 & 0 & 0 & 3 & 4 \\
\hline Kaõnõn & Cassytha filiformis L. & 1 & 0 & 0 & 1 & 2 \\
\hline Kaõrõr & Physalis angulata L. & 0 & 0 & 0 & 3 & 3 \\
\hline Keinabu & Carica papaya L. & 0 & 1 & 0 & 0 & 1 \\
\hline Keinwa & Soulamea amara Lam. & 1 & 0 & 0 & 2 & 3 \\
\hline Kieb & Crinum asiaticum $\mathrm{L}$. & 2 & 1 & 0 & 6 & 9 \\
\hline Kino & $\begin{array}{l}\text { Microsorum } \\
\text { scolopendria } \\
\text { (Burm.f.) Capel }\end{array}$ & 0 & 0 & 1 & 1 & 2 \\
\hline Kiren & $\begin{array}{l}\text { Tournefortia argentea } \\
\text { L.f. }\end{array}$ & 2 & 0 & 0 & 8 & 10 \\
\hline Kõjbar & Ochrosia oppositifolia & 1 & 0 & 0 & 4 & 5 \\
\hline Kõnnat & $\begin{array}{l}\text { Scaevola taccada } \\
\text { (Gaertner) Roxb. }\end{array}$ & 2 & 3 & 0 & 4 & 9 \\
\hline Kõne & $\begin{array}{l}\text { Pemphis acidula } \\
\text { J.R. Forst. }\end{array}$ & 0 & 1 & 0 & 0 & 1 \\
\hline Kõno & $\begin{array}{l}\text { Cordia subcordata } \\
\text { Lam. }\end{array}$ & 2 & 0 & 0 & 1 & 3 \\
\hline Kûtaak & $\begin{array}{l}\text { Allophylus timorensis } \\
\text { (DC.) Blume }\end{array}$ & 1 & 0 & 0 & 2 & 3 \\
\hline Lukwej & $\begin{array}{l}\text { Calophyllum } \\
\text { inophyllum L. }\end{array}$ & 1 & 1 & 0 & 2 & 4 \\
\hline Mã & $\begin{array}{l}\text { Artocarpus altilis } \\
\text { (Parkinson ex Z) Fosb. }\end{array}$ & 0 & 2 & 0 & 3 & 5 \\
\hline Makmõk & $\begin{array}{l}\text { Tacca leontopetaloides } \\
\text { (L.) Kuntze }\end{array}$ & 0 & 2 & 1 & 1 & 4 \\
\hline Mariko & Centella asiatica L. & 0 & 0 & 0 & 3 & 3 \\
\hline Markinenjojo & $\begin{array}{l}\text { Vigna marina (Burm.) } \\
\text { Merr. }\end{array}$ & 2 & 1 & 0 & 3 & 6 \\
\hline
\end{tabular}


Stevens Releford \& McClatchey - Survivor Rongelap: Health issues and use of traditional medicine among the women of Rongelap atoll

\begin{tabular}{|l|l|c|c|c|c|c|}
\hline \multicolumn{2}{|l|}{ Names } & \multicolumn{5}{c|}{ Treatments } \\
\hline Rongelap & Scientific & for Women & for Children & for Men & General & Total \\
\hline Markûbwebwe & $\begin{array}{l}\text { Wollastonia biflora } \\
\text { (L.) DC. }\end{array}$ & 2 & 0 & 0 & 2 & 4 \\
\hline Marlap & $\begin{array}{l}\text { Canavalia cathartica } \\
\text { Thouars }\end{array}$ & 1 & 1 & 0 & 1 & 3 \\
\hline Marpele & Ipomoea violacea L. & 1 & 0 & 0 & 1 & 2 \\
\hline Meria & Plumeria rubra L. & 0 & 1 & 0 & 0 & 1 \\
\hline Nen & Morinda citrifolia L. & 1 & 1 & 0 & 9 & 11 \\
\hline Ni & Cocos nucifera L. & 1 & 2 & 0 & 5 & 8 \\
\hline Pãdãdijmaan & $\begin{array}{l}\text { Fimbristylis cymosa } \\
\text { R.Br. }\end{array}$ & 0 & 0 & 0 & 3 & 3 \\
\hline Pinana & Musa spp. & 0 & 0 & 0 & 3 & 3 \\
\hline Topo & $\begin{array}{l}\text { Ipomoea pes-caprae } \\
\text { (L.) R.Br. }\end{array}$ & 2 & 0 & 0 & 0 & 2 \\
\hline Utilomar & Guettarda speciosa L. & 3 & 2 & 0 & 1 & 6 \\
\hline Wõp & $\begin{array}{l}\text { Barringtonia asiatica } \\
\text { (L.) Kurz }\end{array}$ & 1 & 0 & 0 & 2 & 3 \\
\hline Wũlej & $\begin{array}{l}\text { Clerodendron inerme } \\
\text { (L.) Gaertner }\end{array}$ & 2 & 1 & 0 & 3 & 6 \\
\hline Wũt kio & Sida fallax Walp. & 0 & 0 & 0 & 3 & 3 \\
\hline
\end{tabular}

utilized by members of the community most at risk is included here.

Great care is taken to preserve the health of women through the use of traditional medicine. At birth and through her childhood, a female child is given special herbal baths and external and vaginal remedies to reduce swelling and odor in order to guarantee her sexual beauty in adulthood (Fowler \& Taafaki 2006). Once a young woman begins menstruation she has treatments available to her that control bleeding and regulate her cycle. Other traditional remedies available to young women are used to treat infertility issues, unrequited love and to encourage faithfulness in their husbands.

When a woman becomes pregnant, she is carefully looked after and monitored by the women in her life. She is given daily herbal baths and massage, treatments for morning sickness, and body scrubs to remove unwanted pigmentation (Fowler \& Taafaki 2006). In the final trimester of pregnancy, a woman is given remedies to cleanse her internally and to prepare her for childbirth. As delivery nears, treatments are given to prepare both mother and child for birth. Some of these strengthen the women's body for the impending birth while others encourage contractions and ease pain. Additionally, leaves are rubbed on the woman's chest to drive away evil spirits at this very vulnerable time for mother and child.
After birth, the healer uses traditional remedies to reform the uterus, stop bleeding, and to ease pain and swelling. Following the birth, both mother and child begin a regimen of herbal baths and internal treatments to cleanse and purify and to strengthen and restore health. New mothers are often given energizing remedies that give them the strength and energy needed to care for their child.

Infants and toddlers are also known to be very vulnerable to illness and may not survive to adulthood. As a result, mothers feel very strongly about giving the child the very best chance for survival. Newborn infants receive many of the same treatments as their mother including many of the herbal baths and internal cleansing treatments spoken of previously. Herbal baths and teas in particular are used in the same way American doctors would administer booster shots or vitamins. Rongelap healers have a large repertoire of treatments for many typical childhood ailments. For example, there are six species used to produce remedies for jaundice. Further, healers have remedies to treat coughs and colds, ringworm, diarrhea, fever, allergies, ear infections, cold sores, teething pain, and blisters on the tongues of children.

Rongelap Islanders believe the best way to treat illness is to prevent it from happening. To this end, there are specific medicines and practices designed to keep an individual from becoming ill. Some of these remedies were given strictly to infants and toddlers in order give the child a better start and to help them live a healthy life. Most of 
the other preventative remedies collected were targeted for the more mature members of the community who may need some extra help to remain healthy. These preventative remedies fall into three categories: general dietary supplements, energizing drinks, and those used to prevent specific diseases.

General dietary supplements are taken orally in much the same way Americans would take a multi-vitamin. In some cases, individuals take the supplements on a daily basis and in others they are used for a short time. These supplements are particularly important for infants, pregnant women and new mothers, and the more mature members of the community. Infants are given special medicinal teas as a vitamin source while older men and women utilize fruits and leaves on a daily basis as a general preventative in the same way Americans would take a vitamin. The use of energizing remedies seems to be common among the more mature members of the community, pregnant women, and new mothers. Individuals also use plant extracts in order to prevent specific diseases such as diabetes and cancer.

\section{Discussion}

There is some disagreement and confusion regarding what constitutes a safe annual dose of radiation. The U.S. government has maintained that exposure to 100 millirems (mrem) or 1 millisievert (mSv) annually is acceptable (United States Department of State 2004). The Nuclear Claims Tribunal has adopted the current Environmental Protection Agency (EPA) standard of 15 mrem or $1.5 \mathrm{mSv}-1$ per year as a more appropriate limit (United States Environmental Protection Agency 1997). Based on radiological and dietary surveys conducted in the Marshall Islands including Rongelap atoll, Harvard Law Student Advocates for Human Rights (2006) estimated that individuals living on Rongelap islet within Rongelap atoll whose diet was made up of $75 \%$ local food could receive between 40-240 mrem (4.0 mSv-1-2.4 mSv) annually. Individuals whose diet consisted of only $18 \%$ local food may receive between $12-80$ mrem (1.2mSv-1-8.0mSv-1) annually. The numbers for the northern islets were much higher, from 40-800 mrem (4.0 mSv-1-8.0 mSv), depending on diet. Again, these numbers do not take into account the use of traditional plant-based remedies which could further increase exposure levels particularly if combined with a diet high in locally produced foods.

Our results suggest that certain members of the Rongelap community will likely utilize traditional plant-based remedies more frequently than previously suggested, supporting our hypothesis. Women, young children, and those consuming daily supplements, certainly utilize far more than six doses of a given remedy within a year. In fact, pregnant women will likely utilize nearly forty remedies specific to pregnancy and childbirth throughout the course of pregnancy. Some remedies, particularly those for morning sickness, and those used to prepare for childbirth are employed very frequently if not on a daily basis throughout the pregnancy further increasing the dose numbers.

According to the International Commission on Radiological Protection (ICRP) (1991) the international guideline for ingestion of radiation from medical remedies is $1.0 \mathrm{mSv}$ 1 per year. Duffy et al. (1999) estimated an annual dose of $1.2 \mathrm{mSv}-2$ for the region of the Marshall Islands that includes Rongelap atoll. Again, this estimate is based on the assumption that individuals will ingest only 6 traditional plant-based remedies per year. They further suggest that the maximum dose of radiation from any given single remedy produced in the region may be as much as twenty-four times higher or sixteen times lower than their median numbers depending on species and location, making it even more difficult to quantify true dosage. Based on the median dose calculated by Duffy and her colleagues, Rongelap Islanders who consumed sixty remedies, or five remedies per month, in a given year could potentially receive a dosage ten times greater than previously suggested (1.2 mSv-1) and would exceed the maximum annual dosage guideline of the ICRP. Further, individuals consuming daily supplements could potentially receive a dose over sixty times (7.3 $\mathrm{mSv}-1)$ the previously suggested dose possibly putting the individual at increased risk. Consuming plant-based remedies on a daily basis as preparation for childbirth, or as dietary supplements, may cause individuals to exceed safe levels of radiation exposure and do more harm than good. Additionally, some individuals may be employing more than one dietary supplement daily resulting in much higher levels of exposure than those assumed by Duffy and her colleagues. Although it is more difficult to quantify the risk to children, we recorded twenty-nine remedies that were specific to children. Additionally, general remedies for ailments such as coughs and colds, fatigue, and first aid would certainly be given to children. A child would exceed the previously recorded dosage if they were given even a quarter of these remedies.

Individuals who will be practicing traditional medicine in the role of a healer on Rongelap should also be wary of increased exposure levels. As a result of their increased contact through plant collection and preparation of remedies, they may be exposed to higher levels of radionuclides than other members of the community. Preparation of plant-based remedies involves techniques such as crushing, squeezing, chewing, and massage that could increase his or her exposure levels. Practicing healers often include the more mature members of the community who may also be utilizing daily supplements compounding their possible risk of overexposure. Therefore, to reduce cesium intake healers should employ careful collection and make some changes in preparation techniques. 


\section{Stevens Releford \& McClatchey - Survivor Rongelap: Health issues and use of traditional medicine among the women of Rongelap atoll}

We are not attempting to specifically quantify the increase to exposure levels from the additional use of traditional medicines by Rongelap Islanders, nor are we suggesting that the frequent use of traditional remedies will increase exposure level beyond the suggested safety limits. However, we are suggesting that the risk may be higher than previously reported. Members of the Rongelap Community should be made aware of the potential risks for overexposure from consuming traditional medicinal remedies made from locally grown plant species. Exposure to radionuclides may be reduced, while still allowing Rongelap Islanders to continue using traditional remedies, if precautions are taken. These precautions include some changes in the way Rongelap islanders collect and prepare traditional remedies. We would like to suggest some guidelines that may enable the safe use of plant-based remedies made from plants found and grown within Rongelap atoll.

At the present time, the main islet of Rongelap is the only islet within the atoll on which action towards decontamination has begun. This cleanup effort is well underway, and should be completed prior to repatriation by Rongelap Islanders presumably making it safe to live there (Figures 10-11). Unfortunately, no solid plans have been made to decontaminate the other islets within the atoll; therefore they may not be safe for habitation. In fact, the northernmost islets within the atoll were exposed to higher initial levels of radionuclides and are still contaminated. For this reason, the National Research Council (1994) recommended that these islets not be used as a food source when the atoll is resettled. We further suggest that these islets not be used for collection of medicinal plants for use as remedies.

From our distribution work (Stevens Releford et al. 2009) within the atoll, we determined that all but four (Barringtonia asiatica (L.), Crinum asiaticum (L.) Kurz, Pipturus argenteus (G. Forst.) Wedd., and Vigna marina (Burm.) Merr.) of the species reported to be of medicinal value were available. We did not include the northernmost islets in that work due to distance from Rongelap islet as well as contamination concerns. Therefore, Rongelap healers should not have any reason to travel to the northern islets for plant collection. In fact, with the exception of Bruguiera gymnorrhiza (L.) Lam., which is only found on Arbar, and the four plant species not found within the atoll, healers should be able to find all other medicinal species on Rongelap islet, making it unnecessary to collect from any of the contaminated islets. Within Rongelap islet itself,

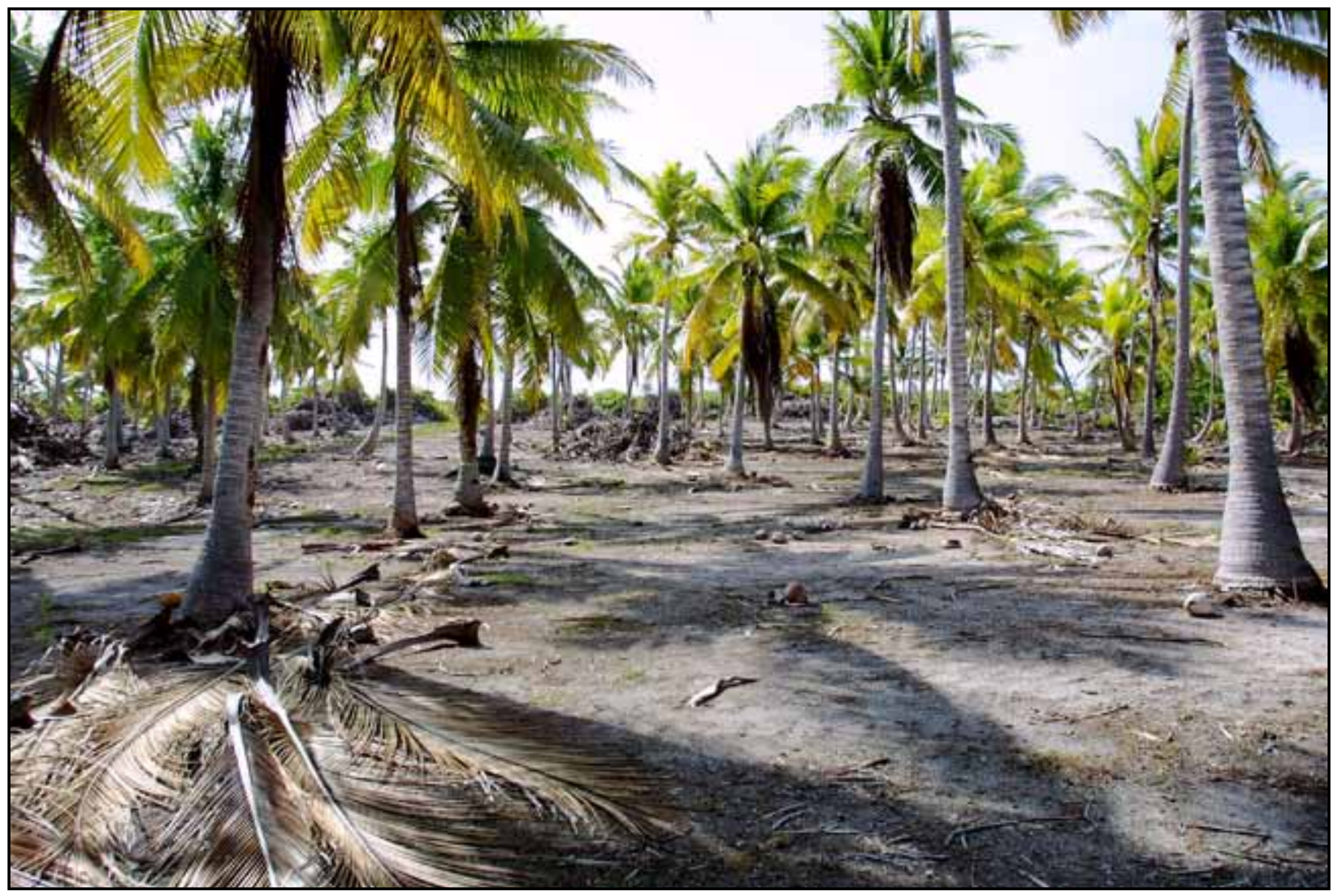

Figure 10. A section of Rongelap atoll. The topsoil has been removed as part of the decontamination process. 


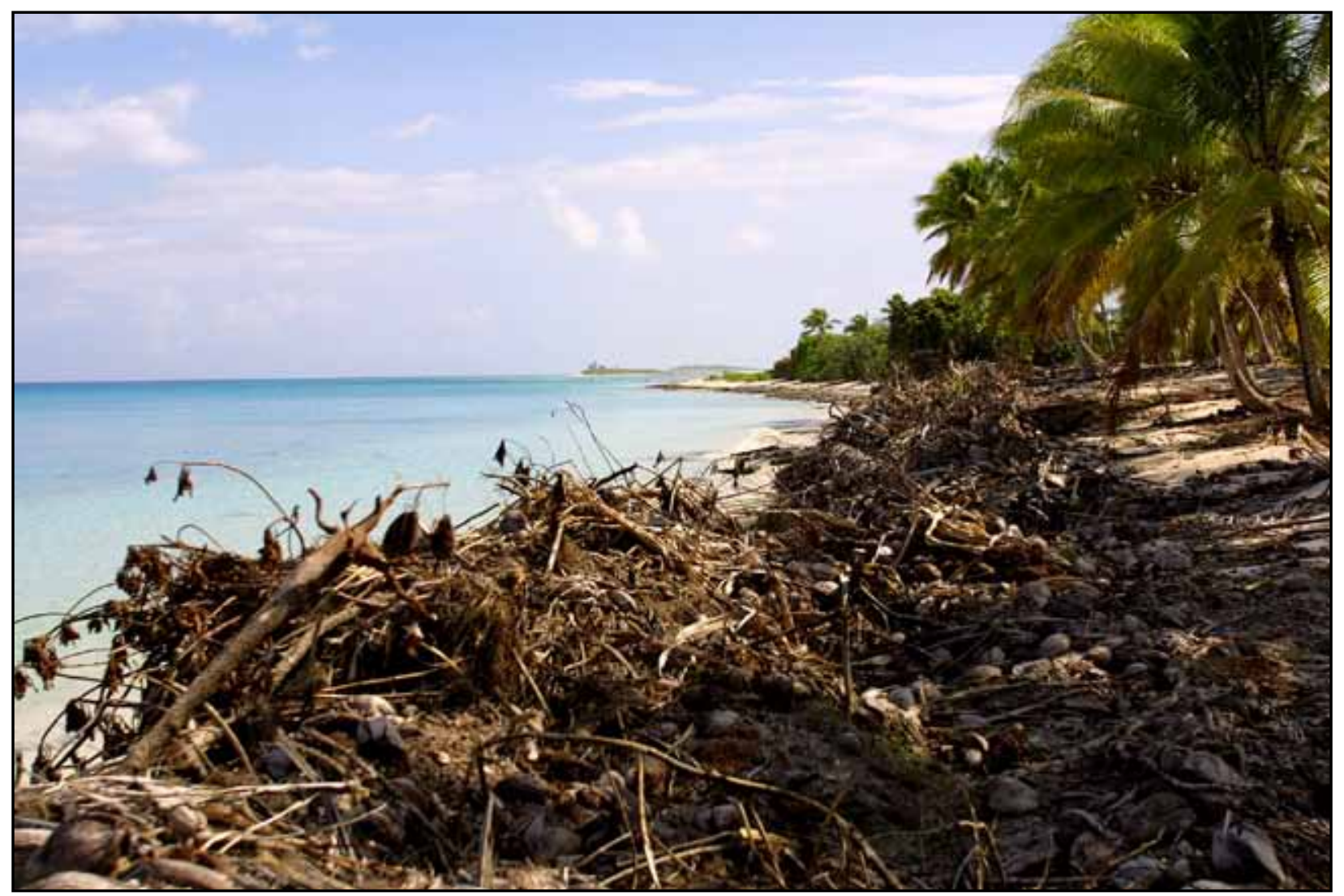

Figure 11. Contaminated debris that has been removed from a section on Rongelap atoll.

there are certain areas that have been determined to be safer for plant collection than others. Areas that have been remediated certainly should be safe. Further, the National Research Council (1994) concluded that the perimeter of the island has lower levels of cesium uptake than the interior. Therefore, plants collected from the perimeter should contribute less to the overall level of exposure and should be chosen whenever possible.

In order to decrease the threat of exposure from medicinal plant use, members of the community may decide to create a medicinal plant garden. By using imported soil and water from the desalinization plant, the threat of exposure would be virtually eliminated. A second option would be to use a hydroponic system, which would eliminate contact with the soil entirely. During our time on Rongelap we were able to successfully create a hydroponic kitchen garden (Figure 12) that could certainly be expanded for community use. A community medicinal plant garden could be maintained by healers or an assigned gardener, and utilized by all.

One plant in particular that ought to be included in such a garden, is kino (Microsorum scolopendria (Burm. f.) Capel) (Figure 13). Duffy and her colleagues (1999) found that kino had significantly higher cesium uptake than the other plants they examined. Therefore, it should be used with caution and in small doses. Planting kino in imported soil or a hydroponic system would make it safe to use regularly.

Further, Rongelap healers may consider changing some of their preparation techniques in order to limit their contact with contaminated plant material. We certainly do not suggest making modifications that would change the efficacy or the cultural significance of the remedies and /or preparation methodology, but we do believe some precautions can be taken without affecting efficacy and cultural significance. For example, instead of chewing ingredients in their mouths they could employ a mortar and pestle to grind the ingredients whenever possible. Further, imported ingredients could be used to replace contaminated local ones such as using baby oil in massage instead of coconut oil for external purposes.

As part of the repatriation process, the National Research Council (1994) suggests that those returning to Rongelap should have an annual whole-body radionuclide count in order to monitor exposure levels in the community. We would also recommend monitoring pregnant women and individuals taking daily plant-based supplements more frequently because of the possible elevated risk from fre- 


\section{Stevens Releford \& McClatchey - Survivor Rongelap: Health issues and use of traditional medicine among the women of Rongelap atoll}

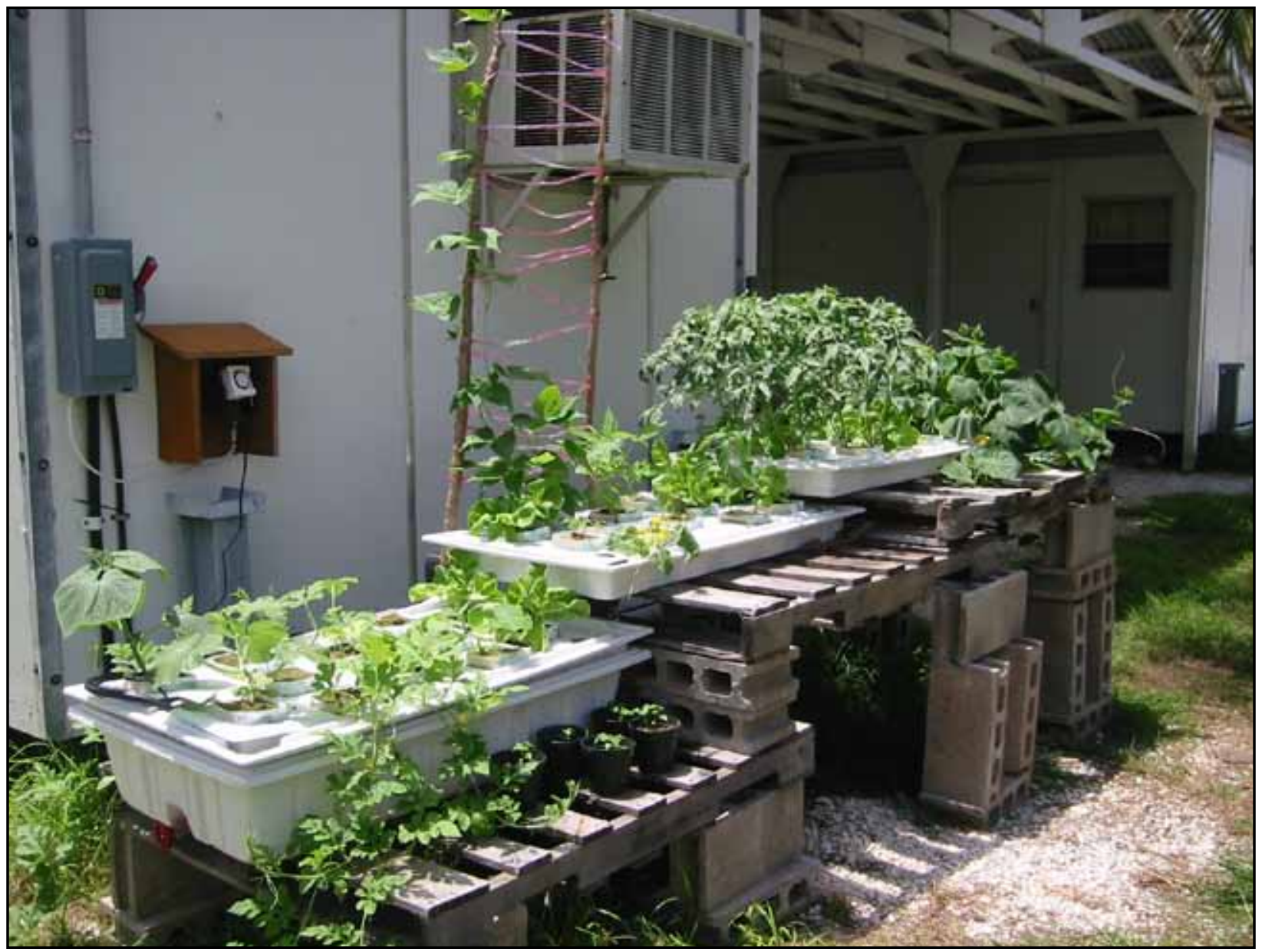

Figure 12. Experimental hydroponic kitchen garden created by the author on Rongelap atoll.

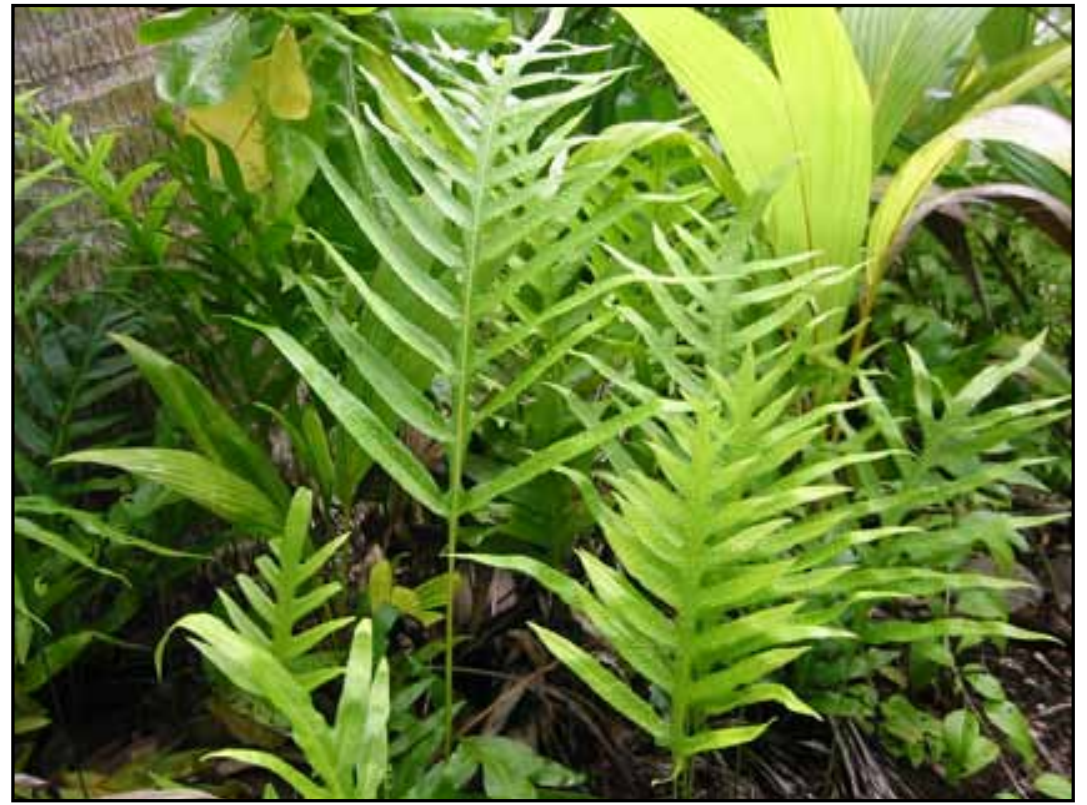

Figure 13. Kino (Microsorum scolopendria (Burm. F.) Copel.) growing on Rongelap atoll. quent use of traditional medicines. Then, if exposure levels rise to unsafe levels, daily therapy may be discontinued or altered immediately. To assist in identifying at-risk individuals, we suggest creating a community questionnaire regarding frequency and type of traditional plant-based remedies utilized by all members of the community. The results of such a questionnaire would aid medical personnel in identifying those at highest risk and enable them to treat those individuals appropriately.

\section{Conclusions}

The women of Rongelap atoll are certainly survivors. They were able to live in one of the harshest environments in the world for centuries by manipulating the environment enough to sustain life. Through their tenacity and 
ingenuity they were able to find numerous ways to use the plants available to them to produce the materials they needed to keep their families and community intact. With the advent of the BRAVO test in 1954, the Rongelap Islanders were given a whole new set of circumstances to live with and adapt to. They have faced a horrific medical legacy, as well as a life of exile, and yet as Senator Abacca Anjain-Maddison said "Through all the hardships and turmoil, we're still here; we've survived” (Marshall Islands Journal 2004). Now these women will have to work together to reestablish a community on Rongelap that is not only viable, but also safe for them and for generations to come.

As Rongelap islanders begin the repatriation process they should be made aware of the possible risks of frequent use of traditional remedies. Particularly those individuals who consume traditional remedies frequently should take precautions in order to keep exposure levels down. With these recommendations in place it should be safe for the returning members of the Rongelap community to utilize traditional plant-based remedies without increasing their exposure levels beyond safe limits. Additionally, if levels do climb, medical personnel should be able to discover the increase and swiftly make recommendations. It is our hope that the information in this work fills a gap that previously existed regarding the use of traditional plant-based remedies by Rongelap islanders and contributes to the repatriation effort by providing a specific plan of action to make the use of traditional medicine safe.

Interestingly, we were not taught any remedies to treat the symptoms of radiation sickness or the thyroid problems and cancers associated with their exposure. While there may be many reasons for this we suspect that the reasons may include the fact that radiation sickness certainly would not be something they would have experienced prior to their exposure in 1954. Additionally, when they were removed from Rongelap atoll the United States government rapidly took over their medical care and testing. From the accounts of survivors there is a feeling that at the time while they were confused and afraid they trusted that medical personnel were treating them properly. Healers may have taken a back seat in cases of radiation sickness based on their inexperience in treating the new symptoms and in deference to the U.S. personnel. Further, some of the effects of radiation exposure such as the growth of thyroid nodules (Howard et al. 1997) and the appearance of cancers take years to appear in the population so would be recent medical maladies for which local remedies have not been developed and tested. Members of the Rongelap community continue to receive medical care and treatment for these diseases from the U.S. government and perhaps there is a feeling that the U.S. doctors have access to more effective treatments thus healers have left the treatment of these diseases to them. That being said, there is still a strong adherence to traditional medicinal practices for other health care matters.
This absence of remedies for symptoms of radiation sickness is interesting and ought to be further investigated in order to better understand the effects of foreign influence on the traditional medicinal practices of populations around the world. Perhaps there is a better way to engage traditional medical practitioners in the process and to work in conjunction with cultural traditions already in place within a given cultural group.

Other indigenous communities with traditional cultural practices elsewhere in the world such as the Sami of Norway (Stephens 1995) or the Pitjantjatjara of Australia (Johnston et al.1992), have had to deal with similar conditions of either exposure to some form of modern industrial contamination or radionuclides from weapons testing, power plant failure, or waste disposal. Increased exposure due to maintenance of the traditional cultural practices needs to be taken into account by policy makers in order to make accurate assessments. Similar studies of environmental exposure (greater or lesser) specifically due to maintenance of cultural practices in the face of adversity should be conducted to develop more clear understanding of the full spectrum of human adaptations that exist in the modern world.

\section{Acknowledgements}

We would like to thank the Rongelap Atoll Local Government for initiating and financially supporting this research. Specifically Mayor James Matayoshi, Abacca Anjain-Maddison, and John Fysh. Members of the Rongelap community both on Rongelap and Majuro made this work possible through their generosity of time and knowledge. We are particularly grateful to Ellen Boas, Aruko Bobo, Isao N. Eknilang, Etri Enos, Norio Kebenli, Rokko Neptali Langinbelik, and all those who participated in focus groups and assisted with translation when necessary. Thanks to Dr. K.W. Bridges for assistance with our transect methodology. We are also grateful for the assistance and friendship of Noel Bigler who will be missed.

\section{Literature Cited}

Alexiades, M. 1996. Collecting ethnobotanical data: An introduction to basic concepts and techniques. Pp. 53-94 in Selected Guidelines for Ethnobotanical Research: A field manual. Edited by M. Alexiades. New York Botanical Garden, Bronx, New York.

Boom, B. 1987. Ethnobotany of the Chacobo Indians. Advances in Economic Botany 4. The New York Botanical Garden, Bronx, New York.

Boom, B. 1989. Use of plant resources by the Chacabo. Advances in Economic Botany 7:78-96. 


\section{Stevens Releford \& McClatchey - Survivor Rongelap: Health issues and use 303 of traditional medicine among the women of Rongelap atoll}

Brooks, A. \& H. Hu. 1995. China. Pp. 487-520 in Nuclear Wastelands: A global guide to nuclear weapons production and its health and environmental effects. Edited by A. Makhijani, H. Hu \& K. Yih. MIT Press, Cambridge, Massachusetts.

Colsher, C., W. Robison \& P. Gudiksen. 1977. Evaluation of the Radionuclide Concentrations in Soil and Plants from the 1975 Terrestrial Survey of Bikini and Eneu Islands. UCRL-51879, Part 3. Lawrence Livermore National Laboratory, Livermore, CA.

Conard, R. 1976. Summary of Thyroid Findings in Marshallese 22 Years After Exposure to Radioactive Fallout. Brookhaven National Laboratory. Upton, New York.

Cooper, M., P. Burns, B.Tracy, M. Wilks \& G. Williams. 1994. Characterization of Plutonium Contamination at the Former Nuclear Weapons Testing Range at Maralinga in South Australia. Journal of Radioanalytical and Nuclear Chemistry 177:161-184.

Crane, P. 1994. Where March 1 Is a Day of Mourning. The Washington Post. March 6.

Cunningham, A. 2001. Applied Ethnobotany: People, wild plant use and conservation. Earthscan Publications Ltd, London.

Defense Nuclear Agency. 1954. Operation Castle, Radiological Safety. Final Report. Volume II. Defense Nuclear Agency, Washington, D.C.

Defense Nuclear Agency. 1979. Compilation of Local Fallout Data from Test Detonations 1945-1962 Extracted from DASA 1251. Defense Nuclear Agency, Washington, D.C.

Department of Energy. 1982. Melelen radiation Ilo koi Ituion Ilo Major, ko Rar etali Ilo 1978 (the meaning of radiation for those atolls in the northern part of the Marshall Islands that were surveyed in 1978). U.S. Department of Energy, Las Vegas, Nevada.

Dibblin, J. 1988. Day of Two Suns. Virago Press, London.

Duffy, S., S.L. Simon, \& F.W. Whicker. 1999. ${ }^{137}$ Cs contamination of plants used for traditional medicine and implications for human exposure. Journal of Environmental Radioactivity 46:27-44.

Fowler, M.K. \& I.J. Taafaki 2006. Women's roles, attributes and health in the Marshall Islands. Pp. 11-18 in Traditional Medicine of the Marshall Islands: The women, the plants, the treatments. Edited by I.J. Taafaki, M.K. Fowler \& R.R Thaman. IPS Publications, University of the South Pacific, Suva, Fiji.
Greenpeace. 2005. Rongelap Evacuation. www.greenpeace.org/usa

Harvard Law Student Advocates for Human Rights. 2006. Keeping the Promise: An evaluation of continuing U.S. obligations arising out of the U.S. nuclear testing program in the Marshall Islands. Harvard Law School, Cambridge, Massachusetts.

Hoover, W. 2003. Bikini Atoll survivors recall horror of nuclear explosion. Honolulu Adverstiser. Sunday, March 2.

Howard, J., A. Vaswani \& P. Heotis. 1997. Thyroid disease among the Rongelap and Utirik population: An update. Health Physics 73:1.

Johnson, G. 1979. Micronesia: America's 'strategic trust.' Bulletin of the Atomic Scientists February:11.

Johnson, G. 1980. Paradise lost. Bulletin of the Atomic Scientists December:28.

Johnston, B. \& H. Baker. 2008. Consequential Damages of Nuclear War: The Rongelap report. Left Coast Press, Inc. Walnut Creek, California.

Johnston, P., K. Lokan \& G. Williams. 1992. Inhalation Doses for Aboriginal People Reoccupying Former Nuclear Weapons Testing Ranges in South Australia. Health Physics 63(6):631-640.

Keju-Johnson. 2003. Nuclear bomb testing on human guinea pigs. Pp. 249-251 in Women on War: An international anthology of writings from antiquity to the present. Edited by D. Goiseffi. Feminist Press, New York.

Kohn, H. 1989. Rongelap Reassessment Project Report. Berkeley, CA. http://worf.eh.doe.gov/data/ihp1d/400005e. pdf (accessed April 12008 ).

Koranda, J., W. Robison, S. Thompson \& M. Stuart. 1978. Enewetak Radioecology Research Program: I. Ecological studies on Enjebi Island 1975-1976. Lawrence Livermore National Laboratory, Livermore, CA. UCRL-52409-1.

Leubben, T. 1988. The Western Shoshone: The land rights struggle of the Western Shoshone Nation. Aboriginal Law Bulletin 2(31):10.

Marshall Islands Journal. 2004. Time to tell the Rongelap story. Marshall Islands Journal. February 6.

Martin, G. 1995. Ethnobotany: A methods manual. Chapman and Hall, London.

Matayoshi, J. 2004. Matayoshi's words capture people's mood. Marshall Islands Journal. March 12. 
Merlin, M., A. Capelle, T. Keene, J. Juvik \& J. Maragos. 1994. Keinikkan Im Melan aelōn: Plants and environments of the Marshall Islands. East-West Center, Honolulu, Hawaii.

Merrill, E.D. 1981. Plant Life of the Pacific World. Rutland, Vt.: C.E. Tuttle Co., Washington.

Muller, F. \& N.V. Velde. 1999. Overview of the Marshall Islands' Forest Resources. Republic of the Marshall Islands Ministry of Resources, Development and Works Agriculture Division.

Murphy, S. 2005. Farewell Rongelap. Marshall Islands Journal March 11.

Nandwani, D. \& E.J. Dasilva. 2003. Traditional knowledge and medicine in the Marshall Islands. ARGRO Food Industry Hi-Tech. July/August.

National Cancer Institute. 2004. Estimation of the Baseline Number of Cancers Among Marshallese and the Number of Cancers Attributable to Exposure to Fallout from Nuclear Weapons Testing Conducted in the Marshall Islands. Prepared for Senate Committee on Energy and Natural Resources. Washington, D.C.

National Research Council. 1994. Radiological Assessments for the Resettlement of Rongelap in the Republic of the Marshall Islands. Committee on Radiological Safety in the Marshall Islands. National Academy Press, Washington, D.C.

Nelson, V. 1977. Radiological survey of plants, animals, and soil at Christmas Islands and seven atolls in the Marshall Islands. Progress Report for 1974-1975. NVO-26932. University of Washington, Seattle, Washington.

Plasman, J. 2005. Testimony before the Committee on Resources and the Committee on International Relations Subcommittee on Asia and the Pacific. "The United States Nuclear Legacy in the Marshall Islands: Consideration of Issues Relating to the Changed Circumstances Petition". May 25.

Pollock, N. 2004. Marshall Islands Women's Health Issues: Nuclear fallout. Presentation for the Asia-Pacific Regional Meeting, Women's International League for Peace and Freedom, Christchurch, New Zealand, February 28.

Prance, G. T., W. Balee, B.M. Boom \& R.L. Carneiro. 1987. Quantitative ethnobotany and the case for conservation in Amazonia. Conservation Biology 1: 296-310.

Robison, W., C. Conrado \& T. Hamilton. 1997. A comparative study on ${ }^{137} \mathrm{Cs}$ transfer from soil to vegetation in the Marshall Islands. Pp. 122-129 in Proceeding of International Meeting on Influence of Climatic Characteristics
Upon Behavior of Radioactive Elements. Edited by Y. Ohmomo \& N. Sakurai. Rokkasho, Aomori, Japan, October 14-16.

Robison, W., C. Conrado \& M. Stuart. 1988. Radiological Conditions at Bikini Atoll: Radionuclide concentrations in vegetation, soil, animals, cistern water, and ground water. UCRL-53840. Lawrence Livermore National Laboratory, Livermore, California.

Robison, W., M. Mount, W. Phillips, M. Stuart, S. Thompson, C. Conrado \& A. Stoker. 1982. An Updated Radiological Dose Assessment of Bikini and Eneu Islands at Bikini Atoll. UCRL-53225. Lawrence Livermore National Laboratory, Livermore California.

Simon, S.L. 1997. A brief history of people and events related to atomic weapons testing in the Marshall Islands. Health Physics 73:5-20.

Simon, S. \& A. Bouville. 2002. Radiation doses to local populations near nuclear weapons test sites worldwide. Health Physics 82(5):706-725.

Spradley, J. 1979. The Ethnographic Interview. Holt, Rinehart \& Winston, New York.

Stanbury, J. 1970. On the use of radioisotopes in human experimentation. The Journal of Nuclear Medicine 11(10):586-591.

Stephens, S. 1995. Physical and cultural reproduction in a post-Chernobyl Norwegian Sámi community. Pp. 270-288 in Conceiving the New World Order: The global politics of reproduction. Edited by F. Ginsburg \& R. Rapp. University of California Press, Berkeley.

Stephens, S. 1997. Lapp life after Chernobyl. Natural History $96(12): 32-42$.

Stevens Releford, J. 2009. The Botany of Rongelap Atoll: A survival story. Ph.D. dissertation. University of Hawaii at Manoa, Honolulu, Hawaii.

Stevens Releford, J., J. Stevens, W. McClatchey \& K.W. Bridges. 2009. Flora of Rongelap and Alinginae Atolls, Republic of the Marshall Islands. Atoll Research Bulletin 572.

Taafaki, I.J., M.K. Fowler \& R.R Thaman. 2006. Traditional Medicine of the Marshall Islands: The women, the plants, the treatments. IPS Publications, University of the South Pacific, Suva, Fiji.

Tamayose, C. 2005. Testimony to the House Resources Committee hearing on the Changed Circumstances Petition. Yokwe Online. www.yokwe.net/modules.php?op=mo dload\&name=News\&file=article\&sid=1095 (accessed on September 1 2008). 


\section{Stevens Releford \& McClatchey - Survivor Rongelap: Health issues and use 305 of traditional medicine among the women of Rongelap atoll}

Takahashi, T., M. Schoemaker, K. Trott, S. Simon, K. Fujimori, N. Nakashima, A. Fukao \& H. Saito. 2003. The relationship of thyroid cancer with radiation exposure from nuclear weapon testing in the Marshall Islands. Journal of Epidemiology 13(2):99-107.

Taylor, W.R. 1950. Plants of Bikini and other Northern Marshall Islands. University of Michigan Press, Ann Arbor, Michigan.

The Hague. 1995. Public sitting in the case in Legality of the Use by a State of Nuclear Weapons in Armed Conflict and in Legality of the Threat or Use of Nuclear Weapons. International Court of Justice. November 14.

Tobin, J. 2002. Stories from the Marshall Islands. University of Hawaii Press, Honolulu, Hawaii.

United States Atomic Energy Commission. 1957. Return of Rongelapese to their Home Island - Note by the Secretary.

United States Department of State. 2004. Report Evaluating the Request of the Government of the Republic of the Marshall Islands Presented to the Congress of the United States of America. United States Department of State, Washington, D.C.

United States Environmental Protection Agency. 1997. Memorandum. Establishment of Cleanup Levels for CERCLA Sites with Radioactive Contamination. Office of
Emergency and Remedial Response, and Office of Radiation and Indoor Air. OSWER No. 9200.4-18. August 22.

Wasserman, H. \& N. Solomon with R. Alvarez \& E. Walters. 1982. Killing Our Own: The disaster of America's experience with atomic radiation. Dell Publishing Co., New York.

Weisgall, J. 1994. Time to end the 40-year lie. Bulletin of the Atomic Scientists May 1.

Weisskopf, M. 1988. Islanders left unaware of A-test hazards; Marshalls residents allege U.S. cover-up to protect weapons program, avoid costly claims. The Washington Post May 31.

Whitcomb, R. 2000. Reconstruction and Analysis of Cesium-137 Fallout Desposition in the Marshall Islands. Doctoral dissertation, University of Florida, Gainesville, Florida.

Woodard, C. 1998. Marshall Islands: You can't go home again. Bulletin of the Atomic Scientists September 1.

Yamazaki, J. 1995. Children of the Atomic Bomb: An American physician's memoir of Nagasaki, Hiroshima, and the Marshall Islands. Duke University Press, Durham, North Carolina. 